\author{
Working Paper No. 2012/20
}

\title{
Foreign Aid and Democratic Development in Africa
}

\section{Simone Dietrich ${ }^{1}$ and Joseph Wright ${ }^{2}$}

February 2012

\begin{abstract}
Over the past two decades, donors increasingly linked foreign aid to democracy objectives in sub-Saharan Africa. Yet systematic research on this topic typically focuses on how aid influences democratic transitions. This study investigates whether and how foreign aid affects the process of democratic consolidation in sub-Saharan Africa by examining two potential mechanisms: (1) the use of aid as leverage to buy political reform, and (2) investment in the opposition. We test these mechanisms using five dependent variables that capture different aspects of democratic consolidation. Using survival analysis for the period from 1991 to 2008, we find that democracy and governance aid has a consistently positive effect on democratic consolidation. Economic aid, on the other hand, has no effect on democratic consolidation.
\end{abstract}

Keywords: Africa, democratic consolidation, foreign aid, survival analysis JEL classification: C41, D72, F35, N47

\section{Copyright (C) UNU-WIDER 2012}

1 Princeton University, email: dietrich.simone@gmail.com; 2 Corresponding author. Pennsylvania State University, email: josephgwright@gmail.com

This working paper has been prepared within the UNU-WIDER project 'Foreign Aid and Democracy in Africa' directed by Danielle Resnick, which is a component of the larger UNU-WIDER programme 'Foreign Aid: Research and Communication (ReCom)'. UNU-WIDER gratefully acknowledges specific programme contributions from the governments of Denmark (Ministry of Foreign Affairs, Danida) and Sweden (Swedish International Development Cooperation Agency-Sida) for the Research and Communication (ReCom) programme. UNU-WIDER also acknowledges core financial support to UNUWIDER's work programme from the governments of Finland (Ministry for Foreign Affairs), the United Kingdom (Department for International Development), and the governments of Denmark and Sweden. 
The World Institute for Development Economics Research (WIDER) was established by the United Nations University (UNU) as its first research and training centre and started work in Helsinki, Finland in 1985. The Institute undertakes applied research and policy analysis on structural changes affecting the developing and transitional economies, provides a forum for the advocacy of policies leading to robust, equitable and environmentally sustainable growth, and promotes capacity strengthening and training in the field of economic and social policy making. Work is carried out by staff researchers and visiting scholars in Helsinki and through networks of collaborating scholars and institutions around the world.

www.wider.unu.edu publications@wider.unu.edu

UNU World Institute for Development Economics Research (UNU-WIDER)

Katajanokanlaituri 6 B, 00160 Helsinki, Finland

Typescript prepared by Janis Vehmaan-Kreula at UNU-WIDER

The views expressed in this publication are those of the author(s). Publication does not imply endorsement by the Institute or the United Nations University, nor by the programme/project sponsors, of any of the views expressed. 


\section{Introduction}

This study examines the empirical relationship between foreign aid and democracy in sub-Saharan Africa (SSA). In the wake of the Cold War many countries in the region adopted multiparty politics. However, while politics has become less personalized and more institutionalized in the past two decades, the shift to multiparty politics has not led to a wave of consolidated democracies (Posner and Young 2007; Cheeseman 2011). In the 18 years from 1991-2008, incumbent leaders have left power only eight times after losing elections under established multiparty regimes. 1 For many countries in the region, multiparty politics still means that the incumbent remains in office, thus falling short of developments that represent democratic deepening.

To improve our understanding of what accounts for democratic deepening in Africa we build on the existing literature in two ways. First we distinguish among different purposes of aid by analyzing economic aid flows alongside aid flows that are earmarked specifically for democracy promotion. The latter category of aid comprises assistance to strengthen public institutions and the civil society sector. 2 To date, most of the empirical work that investigates the link between aid and democracy measures aid at its highest level of aggregation, grouping all categories of aid together (Goldsmith 2001; Knack 2004; Dunning 2004; Djankov et al. 2008; Wright 2009; Bueno de Mesquita and Smith 2010; Bermeo 2011). More recently, however, scholars have begun narrowing their scope to focus specifically on how democracy and governance aid influences democracy to better understand the channels through which foreign aid may affect democracy (Finkel et al. 2007; Scott et al. 2011). Second, we look at different stages of the democratic trajectory by presenting empirical analyses that assess the link between aid and transitions to multiparty politics and the relationship between outside financial assistance and democratic consolidation.

We begin by describing the general patterns of aid flows, both for total and democracy and governance aid. Figure 1 shows the flow of foreign aid to the region from 19902008. The total aid sum is the combined aid flows to all 48 SSA countries from Western donors in the Organization for Economic Cooperation and Development (OECD). ${ }^{3}$ The per capita figure is the average per capita across all 48 countries. As the upper panel indicates, foreign assistance to the region declined in the early 1990s, in part because major Western aid donors decreased support for client states after the end of the Cold War. However, by the end of the decade this trend had reversed. Average aid per capita jumped from less than US\$70 per person in 1997 to over US\$115 by 2008. The Ushaped aid trend in the region can, in part, be explained by the shift in donor goals amidst a changing global order (Dunning 2004; Bermeo 2009; Bearce and Tirone 2010). When Western donor countries were no longer threatened by Soviet influence, we observe a substantial reduction in aid volumes to the region immediately after the Cold War. Yet, as donor countries grew increasingly alarmed by the prospects of failed states in the region, foreign assistance increased.

1 These include Benin 2001, Cape Verde 2001, Ghana 2000, Guinea-Bissau 2000, Kenya 2002, Madagascar 1996, Mali 2002, and Senegal 2000. See footnote 11.

2 See section 3 for detailed description of the data categories.

3 There are only totals for 47 countries prior to 1993, when Eritrea becomes an independent state. We note that the foreign aid we examine comes from Western donors. 
The purpose of democracy and governance aid as a separate category in development assistance has also changed over time. During the Cold War, foreign aid was primarily viewed as a tool to counter Soviet influence, as opposed to representing a desirable end goal (Ake 1996; Crawford 1997; Dunning 2004). Over the past two decades, however, donors have steadily increased democracy and governance aid throughout the world and particularly in SSA. The lower panel of Figure 1 shows that total democracy assistance, both bilateral and multilateral, has nearly quadrupled-albeit from a low base-from 1990 to 2008

Figure 1: Aid commitments to SSA
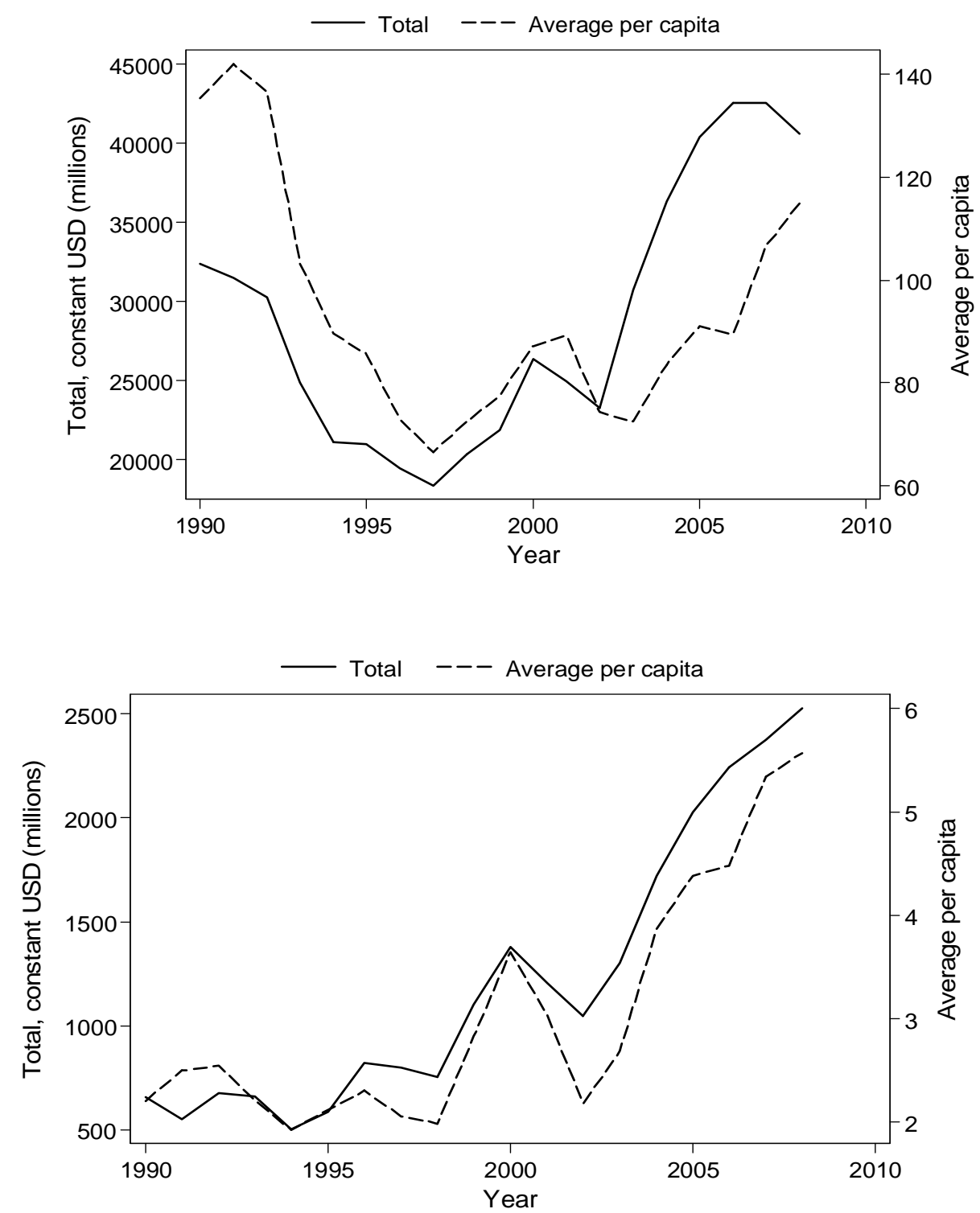

Note: The upper panel is aid from all categories; lower panel democracy and governance aid. Total is constant US\$ in millions. Per capita is constant US $\$$ averaged across 48 countries. Two year moving average $(\mathrm{t}, \mathrm{t}-1)$.

Sources: AidData.org, WDI (2010), and authors' calculations. 
Figure 2: Total democracy and governance aid and US democracy and governance aid to SSA, shares
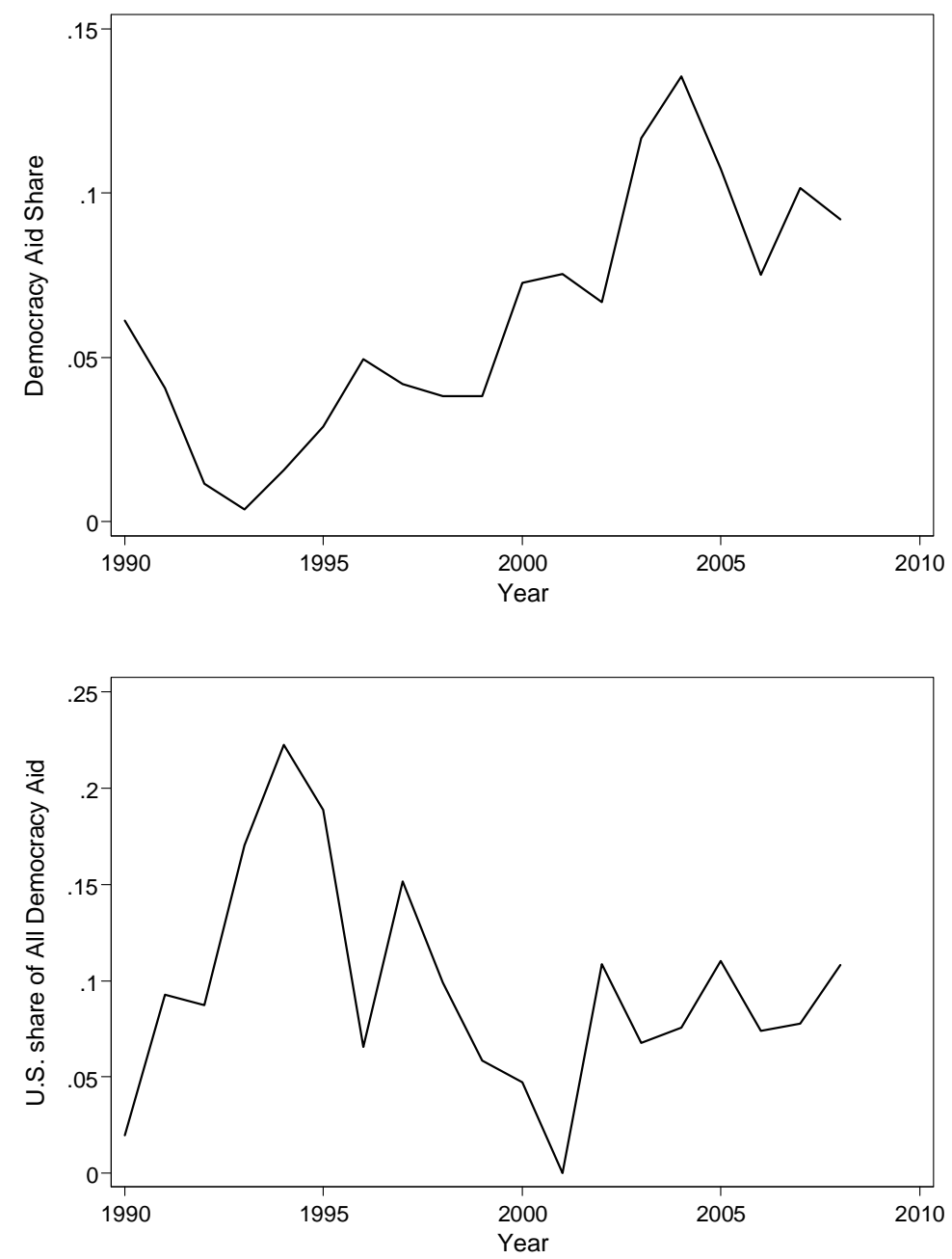

Notes: Shares are two-year ( $\mathrm{t}, \mathrm{t}-1)$ moving averages of yearly shares in constant dollars: and

\section{USDemocracyAid}

AllDemocracyAid.

Sources: AidData.org, WDI (2010), and authors' calculations.

The upper panel of Figure 2 illustrates changes in the proportion of democracy and governance aid across time, ranging between one and nearly 15 per cent of total aid flows to the region. While the share of democracy aid was around 5 per cent in 1990, donors initially directed aid away from this sector in the early 1990s. From 1993 onwards, however, the overall trend is upwards, suggesting increasing donor preferences for democracy and governance aid.

The rise of democracy and governance aid can be explained in part by a shift in policythinking about the role of democracy in implementing economic reforms. First made explicit in a 1989 United Nations report on sustainable economic reform in Africa, policy makers started to focus on the political and institutional factors that underpin growth (Lancaster 1993; Crawford 2001). To quote Crawford (2001: 13): 'In a shift from previous prevailing wisdom - that authoritarian governments were better placed to implement harsh economic adjustment measures-the view of a positive interrelationship between democracy and economic liberalization became widespread'. 
Democracy and good governance were no longer afterthoughts in development policy discussions, and linking foreign aid to improvements in these areas came into vogue. The new thinking about the role of democracy in economic development also gave a positive rationale for both providing democracy assistance in the first place and conditioning economic aid on political reform.

Research has since incorporated the fact that aid is often linked to political reform in recipient countries during the post-Cold War period, and has found that the relationship between aid and democracy may differ by period. For example, Dunning (2004) shows that the positive effect of aid on democracy in Africa only occurs after 1989 because the threat of Western donors revoking aid was more credible during that period. Heckelman (2010) also finds a positive correlation between aid per capita and democracy in Eastern Europe and the former Soviet Union during the decade from 1997, while Wright (2009) shows that aggregate aid is associated with democratic transitions in large coalition dictatorships - but again only in the post-Cold War period. Similarly, Bermeo (2009) finds that foreign assistance only stabilizes authoritarian countries before the 1990s.

The growing evidence that foreign aid may be positively linked with democratic political change since the end of the Cold War presents scholars with a further set of questions. Most of this literature assumes that the mechanism linking aid to democratic change runs through aid conditionality imposed by Western donors. Some case study evidence supports this possibility as well. For example, Handley (2008: 3-4) notes in her study of aid in Ghana that 'consistent pressure from the international financial institutions (IFIs) and associated donors motivated Rawlings to consider liberalization of the political regime and a return to constitutionalism'. However, in light of the difficulties associated with the successful implementation of conditionality, there remains a fair amount of scepticism for this explanation (Collier et al. 1997; Berlinschi 2010). What is more, the decision to treat all aid flows alike, assuming that they all advance donor conditionality goals in the same way, does not tell us whether conditionality explains the empirical pattern after 1990.

More recently, a handful of studies have investigated democracy and governance aid as a separate sector, but this research restricts its analysis to US foreign democracy assistance (Finkel et al. 2007; Scott et al. 2011). 4 While US assistance for democracy programmes is quite large, it nonetheless represents only a fraction of total democracy aid from all Western donors. The lower panel of Figure 2 shows that the trend towards greater democracy promotion efforts in the past two decades reflects the policy choices of many OECD donors, not just the United States. In fact, the US share, while comprising over 20 per cent of all democracy assistance in the early 1990s, has declined over time and ranges between eight and ten per cent for most of the first decade of the new Millennium. Importantly, the bulk of democracy and governance aid in SSA comes from OECD donors outside of the US.

Thus, we still do not know whether economic aid, which comprises the greater part of total aid, or democracy assistance can explain the observed relationship between aggregate aid and various measures of democratic change. The end of the Cold War sparked a shift in donor practices, leading to two changes in aid allocation practice that could potentially influence democracy in recipient countries: (1) donors promote

4 One exception is Kalyvitis and Vlachaki (2010). 
democracy by attaching political reform conditions to economic aid; and/or (2) donors directly invest in democracy promotion through democracy-related aid activities to strengthen public institutions and civil society. While the first mechanism captures donor attempts to buy political reform through economic assistance, the latter mechanism captures donor intent to directly invest in specific democracy promotion activities abroad. By looking at economic and democracy and governance aid separately, we can gain some purchase on the potential mechanisms shaping the relationship between aid and political change.

Under what conditions do economic aid and democracy and governance aid influence democratic consolidation in SSA? To answer this question we advance a theoretical framework that relies on variation in the legacy of military rule and neopatrimonial political practice (Lemarchand 1972; Bratton and van de Walle 1997; Moss et al. 2006). First, we posit that foreign aid can buy liberalizing political reform when the costs of these political concessions to the incumbent are relatively low. Transitions to multiparty politics should be less costly to incumbents who are more likely to survive reform with some claim on political power. This latter condition is more likely, we argue, when the country has civilian rather than a military leader because non-military incumbents typically have a broader and deeper support coalition than their military counter-parts. The depth and breadth of the incumbent coalition means these rulers are more likely to retain some political power despite liberalizing political reform. The trade of aid for political reform is therefore less costly and more likely when the reform simply entails the introduction of multiparty politics and the incumbents are non-military rulers.

Second, we posit that the legacy of personalist rule may condition how foreign aid investments in the democratic political process influence consolidation. In multiparty regimes where neopatrimonial practices persist, democracy and governance aid should have less impact on consolidating democratic politics because elections are more likely to entrench incumbents in power for the long term, raising the costs of losing. Aid investments in this process may reinforce winner-take-all politics and are less likely to help multiparty politics persist. In contrast, where institutionalized politics is the norm, we argue that democratic investments are more likely to further democratic consolidation. We discuss these two theoretical possibilities in greater detail below, but note here that the mechanisms which link foreign aid to the process of democratic consolidation in the past two decades is shaped by the legacy of prior political practice, which varies considerably across the region.

Finally, while previous work typically uses broad measures of democracy or regime stability (Goldsmith 2001; Knack 2004; Dunning 2004; Finkel et al. 2007; Djankov et al. 2008; Wright 2009; Bueno de Mesquita and Smith 2010; Bermeo 2011) we employ several measures of democratic consolidation that isolate what may be qualitatively distinct types of political change, such as the transition to multiparty regimes, the survival of multiparty politics, incumbent turnover under electoral regimes, and respect for term limit rules. As we discuss below, aggregate measures of democracy frequently cannot distinguish between these types of political change because they entail different degrees of threat to the incumbent. Nor can these measures capture democratic development equally well across all regions of the world.

In the next section we briefly review the literature on aid and democratization, highlighting the possibility that a legacy of neopatrimonialism in Africa may influence 
how foreign aid affects democracy in the region. The second section discusses the concept of democratic consolidation and proposes four measures that capture different dimensions of this phenomenon. The third section introduces the foreign aid data and measures of institutional legacy, and discusses our research design. The fourth section reports the results, and the final section concludes with a discussion of the causal mechanisms that might explain the relationship between different types of aid and democratic consolidation.

\section{Aid and democratic consolidation in Africa}

A central argument in the foreign aid literature suggests that aid may hinder democratic deepening by fostering 'bad' institutions (Bauer 1971; Harford and Klein 2005; Moss et al. 2006; Djankov et al. 2008). This view frequently groups foreign aid together with other types of 'unearned income', such as natural resource wealth, to argue that non-tax revenue enables leaders to forgo taxing the citizenry, resulting in a decreased demand for representative democracy and good governance (Levi 1988; North and Weingast 1989; Tilly 1990; Moore 1998). Evidence also exists that suggests that foreign aid may undermine the ability of governments to budget appropriately (Brautigam and Knack 2004; McGillivray and Morrissey 2001) and that foreign aid is used to pay out rents (Remmer 2004; Djankov et al. 2008). In addition to hurting state capacity and supporting rent-seeking, foreign aid dependency may also have a direct detrimental effect on democratic development (Brautigam 2000; van de Walle 2005).

At the same time, a separate line of inquiry investigates targeted investment in democracy (Finkel et al. 2007; Scott et al. 2011). This research disaggregates foreign aid flows and directly tests the link between democracy and governance aid and democratic development. These studies posit that democracy aid influences democracy differently than economic aid. For instance, Finkel et al. (2007) show that US democracy aid has a moderate, yet consistently positive effect on aid-recipient countries' movement towards higher levels of democracy, measured across Polity and Freedom House scores. They suggest that US investment in democracy empowers particular agents (e.g. political organizations and social movements) and strengthens state institutions. Scott et al. (2011) find evidence that US democracy assistance increases democracy but economic aid has a negative effect.

While both research efforts examine global patterns, they do not discuss region-specific effects of aid on democratic consolidation. Scholars of African political economy frequently focus on the subversive effects of foreign aid on the survival of democracy (Bratton and van de Walle 1997; Moss et al. 2006). For decades scholars have identified informal institutions such as clientelism, prebendalism, and the rentier state as obstacles to economic and democratic development (Lemarchand 1972; Bates 1981; Joseph 1987).

Although a series of contested elections in the 1990s provided reason for optimism in the region, many multiparty elections 'encouraged a scramble for high positions in which an expanded array of contenders used proven tactics of future material benefits to loyal votes' (Bratton and van de Walle 1997: 121). Thus, democratic change in the 1990s may have been more of a face-lift than a fundamental change in the nature of politics. In 1997 nearly half of the autocratic leaders in Africa who ruled prior to 1990 remained in power despite elections (Baker 1998). As Lindberg (2006: 13) argues: 
'[t]hese incumbents, even though elected, are not necessarily interested in transforming old structures, since their rule-even as leaders of democratically elected governments-is dependent on old and often clientelistic structures of governance'. The continuity of neopatrimonial practices therefore poses an immediate threat to the consolidation and survival of democracy in Africa.

In light of the negative influence of neopatrimonial practices on economic development and democratic consolidation in SSA, we ask whether donors can overcome these structural obstacles and positively influence democratic consolidation through aid flows. Building on the literature that advocates an aid-hurts-democracy thesis, we posit a working null hypothesis that foreign aid should not strengthen democratic development in Africa. Economic aid, for example, should either not be associated with measures of democratic political change or have a negative effect.

Whether the working null-hypothesis proves correct, it provides little reason to expect the influence of aid on democratic development to operate differently across African democracies. Given the pervasiveness of neopatrimonialism in the region, however, there is reason to believe that these informal practices may condition the effect of aid on democratic development. Specifically, we examine variation in political institutionalization across African democracies. We conceptualize institutionalization of politics as a departure from neopatrimonialism and personalist politics. 5

Regimes with low levels of prior institutionalization have less experience dealing with dissent through formal political institutions such as political parties and legislatures. For democracies whose prior level of institutionalization was low, the prospects of further democratic consolidation may entail greater uncertainty. What is more, the institutionalization of politics can lower the costs of losing power as democratic systems mature. In a polity where personalism dominates, holding power means unparalleled access to state resources for political and personal uses. Political reform that increases the likelihood of losing power would be costly because the leader (or party) not only loses access to current resources but may stand little chance of gaining power in the future without resorting to violence.

In contrast, in democracies where the prior level of institutionalization is high, democratic reforms may be less risky because experience in successfully co-opting dissent under electoral regimes increases the chances incumbents will succeed in increasingly competitive electoral environments. Further, losing power in an institutionalized regime may not entail giving up full access to political power now or in the future. If institutionalization breeds 'more robustly competitive' elections (Posner and Young 2007: 121), then current contestation could bode well for winning power back after having lost it peacefully. Thus our first alternative expectation is that the exchange of aid for political reform may be more attractive when the costs of losing power are relatively low, and a legacy of political institutionalization may lower these costs.

Second, mirroring the logic of a poverty trap in development economics, there may be threshold of prior institutionalization above which investments in democracy and

5 See Pitcher et al. (2009) for discussion of how the term neopatrimonialism may refer to different concepts. 
governance aid yield positive returns. That is, in poorly institutionalized regimes, foreign support for democracy-related activities such as elections and party development may be wasted simply because this investment requires a group of actors (e.g. a political party) sufficiently well organized to benefit from democratic investments. Typically, however, groups in former personalist regimes lack the resources and infrastructure to develop independent organizations and collective action capacity.

We therefore investigate two mechanisms that might link aid to democratization in Africa: (1) aid conditionality attached to economic aid can buy political reform; and (2) democracy and governance aid can help strengthen democracy by investing in key democracy actors and institutions such as opposition parties, civil society groups, and independent electoral commissions. Before we proceed to the research design, however, we briefly define the phenomenon that we seek to explain: democratic consolidation.

\subsection{Conceptualizing and measuring democratic consolidation}

Democratic consolidation can be a difficult concept to measure (Munck and Verkuilen 2002). Much of the study of democracy entails examining the correlates of democratic transitions (Przeworski et al. 2000; Boix and Stokes 2003), and we will follow this tradition by examining how aid relates to transitions to multiparty regimes. However, the determinants of transition to multiparty politics may differ from the factors that help democracies consolidate and endure.

For instance, the introduction and persistence of multiparty politics may not be threatening to some incumbents. In some countries with long-ruling dominant parties, such as Botswana and Tanzania, the introduction of multiparty politics has not led to sufficiently competitive opposition parties that can credibly threaten incumbent rule. In other countries, such as Malawi, the advent of multiparty elections coincided with the transfer of power from a long-ruling leader (Banda 1993). Other forms of democratic deepening, such as incumbent turnover in a multiparty regime, are inherently threatening to the ruling leader and party. We thus investigate different forms of democratic consolidation that characterize the continuation of the democratic regime, conceptualizing consolidation as 'preventing democratic breakdown' (Schedler 2001: 67). 6

The following analysis does not focus on elections per se and thus the data is not organized according to 'founding' and 'second' elections (Bratton 1998; Lindberg 2006). That said, our measures capture aspects of electoral activity. For example, we examine the persistence of multiparty regimes, which incorporates elected legislatures into the definition. We also attempt to measure the fairness of the electoral process. Further, we take up the question of incumbent turnover, which is defined as a candidate from an opposition party winning an executive election. When analyzing each of the various measures of consolidation, we account for time dependence which is

6 This definition has been in used in previous comparative research on democratic consolidation (Svolik 2008; Wright 2008), and is at the heart of the transitions literature, appearing in empirical models which examine transitions from democracy to dictatorship (Przeworski et al. 2000; Boix and Stokes 2003; Epstein et al. 2006). 
conceptually akin to grouping election events by whether they were the first, second, or third to occur without interruption.

We begin by assessing how foreign aid influences transitions to multipartyism. We define multipartyism as the existence of an opposition party (not part of the regime front) in an elected legislature. Minimally, this entails universal suffrage, ${ }^{7}$ an elected legislature, legal opposition parties, and at least one party outside the regime front with seats in the legislature. 8 This definition of multipartyism excludes regimes that allowed opposition parties but never had an election to place them in a legislature (e.g. former Zaire from 1992-97). It also says nothing about electoral fairness or civil liberties, and thus groups together countries with relatively non-violent and fair elections (Botswana) with countries which sometime have unfair and often violent multiparty elections (Kenya after 1992 and even Equatorial Guinea after 1993). Note that there can be more than one transition to multipartyism for a particular country within the sample period if an initial multiparty period ended (Congo-Brazzaville 1992-97) and the country restarted multipartyism at a later date (e.g. Congo-Brazzaville 2002).

For some scholars, multipartyism is a minimal condition for democratization (Cheibub et al. 2010). Here we note two features of transitions to multipartyism that are particularly relevant for assessing the influence of foreign aid. First, these transitions are easily observable. Donors can relatively cheaply and objectively identify whether multiple parties compete for and hold positions in an elected legislative body. Second, the introduction of multipartyism need not pose a direct threat to the incumbent regime. As Posner and Young (2007) note, despite recent advances in the institutionalization of politics, incumbents still rarely lose power in SSA. Below, we examine how democracy and governance aid and economic assistance influence the advent of 48 multiparty transitions between 1989 and 2008, beginning with Benin's National Conference in 1990.

Our second measure of consolidation is the breakdown of a multiparty system, or multiparty failure. After a country has transitioned to a multiparty regime, it then becomes at risk of reversal.

We define multipartyism failure as any one of the following occurring:

(a) government change via a coup or replacement of the leader/party during a violent civil conflict;

(b) institutional change that excludes the opposition, such that opposition parties are illegal or no party outside the regime front is seated in the legislature;

(c) opposition withdraw so that there is no party outside the regime front seated in the legislature.

Assassination of a leader does not end multipartyism unless this results in an opposition executive taking power or the closing of the legislature.

7 We added the suffrage rule to allow the start of multiparty politics in South Africa (1994) and Zimbabwe (1980) after the end of restricted suffrage rule.

8 These latter three features are coded from Cheibub et al. (2010) and double checked by the authors. 
The March 2003 coup in the Central African Republic, in which the former Army Chief of Staff-François Bozizé-ousted Félix Patassé, is an example of (a). After the coup, Bozizé suspended the constitution and abolished the legislature. The Central African Republic had been a multiparty state since the first multiparty election in September 1993. Charles Taylor's government in Liberia banned all opposition parties in April 2002, marking the end of multipartyism (b). He had won the prior election (1997) by a large margin, though the opposition UP (Johnson-Sirleaf's party) secured seven seats, marking the start of multipartyism. The next scheduled election (2003) never took place. Finally, all the main opposition parties in Comoros, including the Movement for Democratic Progress (MDP-NGDC) and the former authoritarian party UDZIMA, boycotted the December 1996 legislative elections. The only other party to win legislative seats was allied with the ruling National Rally for Development. The election boycott ended multipartyism (c). Table A1 lists the multiparty sample.

This is an expansive group of countries defined by observable indicators of multiparty representation in the legislature. It assumes a transition to multipartyism has already occurred and does not define the group of countries that can consolidate by how long multipartyism has been in place. We therefore include observations from multiparty systems that failed to reach a second multiparty election. The third measure addresses the fairness of the electoral political system as measured by the Freedom House political rights (PR) scale. We begin with the sample of multiparty observations and exclude all observation years for which PR is greater than 4 on a scale of 1 (most political rights) to 7 (least). Therefore the sample of countries at risk of failure includes multiparty regimes with a 4 or less on the PR scale. Failure events are coded as either a multiparty failure (see above) or a change in PR from 4 or below to 5,6 , or 7 . We call this variable fairness failure.

This coding procedure excludes regimes that hold multiparty elections that are unambiguously unfair-such as those in Equatorial Guinea, Côte d'Ivoire, and Guinea - from the sample of fair multiparty regimes. It marks failure when the political system under a previously fair multiparty regime turns unfair, even if it does not end the multiparty regime. For example, prior to the 2006 presidential election the Gambia, President Jammeh's government arrested three leading opposition members and passed new legislation that made libel against the government an offense punishable with imprisonment for six months. When multipartyism ends and the multiparty regime was also coded as fair, then a fairness failure occurs (e.g. 1996 coup in Niger). Table A2 lists the fairness failure sample.

The last two measures of consolidation (multipartyism and electoral fairness) are closely related concepts. Many of the events coded as multiparty failure are also coded as fairness failure. The main difference between these two measures is in how the sample is defined and not the key failure event that we model empirically. While the events that typically mark the end of these regimes are threatening to the incumbent (e.g. a military coup or rebels chasing the incumbent from power), the persistence of either of these states is not. We point this out because measuring consolidation as the survival of multipartyism (or electoral fairness) is often not threatening to incumbentsparticularly incumbents who are well placed to win multiparty elections. In contrast, the next two measures of consolidation, incumbent turnover and respect for term limits, are inherently threatening to incumbents. 
The fourth measure of consolidation is incumbent turnover via an election when the country was a multiparty regime in the prior year. 9 This measure excludes electoral incumbent turnover that occurs in the same election in which the country transitions to multipartyism. 10 This dependent variables is coded ' 1 ' for years in which an elected incumbent executive leaves power and a candidate from an opposition party is voted into power. There are eight instances of incumbent turnover in the data set: Benin 2001, Cape Verde 2001, Ghana 2000, Guinea-Bissau 2000, Kenya 2002, Madagascar 1996, Mali 2002, and Senegal 2000.11 The variable is coded ' 0 ' for all other years of multipartyism. In the empirical analysis, we only examine executive election years because these are the only years when an incumbent is truly at risk of losing power via an election. 12 Table A3 provides the data for incumbent turnover.

Our final measure is term limit violation. The base sample begins with executive terms under multipartyism.13 Failure is coded ' 1 ' when the number of terms was changed (Djibouti 2010), the limit was abolished (Cameroon 2008, Niger 2009), or the incumbent leader did not hold an election before the end of the initial term-spell (Angola 2002).14 Country-term-spells constitute consecutive terms permitted before the limit is reached.15 Term-spells are treated as right-censored for multiparty regimes that end before the term limit is reached 16 or when end of the term-spell is later than 2010.17 We collected information on all leaders who: ended their constitutional term; did not successfully change their original term mandate; or were not right-censored. We treat term-spell as the unit of analysis (not country-year), which leaves us with 34 post-1990 term-spells that are not right censored. Of these, 11 are coded term limit violations. Table A4 provides the data for limited terms, including the consecutive term-spell number (first, second or third), whether the term-spell is censored and whether it was violated.

9 Note that this is a positive conceptualization of 'consolidation', where the incumbent who leaves power was an executive in a multiparty regime.

10 For example, Banda losing the 1994 election in Malawi is coded as a transition to multipartyism but not considered an incumbent turnover under a multiparty regime.

11 Nigeria 1993 and Côte d'Ivoire 2000 are not counted because these elections were annulled. São Tomé and Principe 1996 is not counted as turnover because even though ADI did not control the legislature, the winning candidate, Travoada, was the sitting incumbent. Malawi 2009 is not coded incumbent turnover because although the incumbent (Mutharika) switched parties (UDF to DPP), he still won re-election.

12 Election years taken from the Database of Political Institutions (Thorsten et al. 2001).

13 We exclude Lesotho and Mauritius because they are parliamentary systems. Ethiopia is a nominal parliamentary system as well, but is not part of the sample because it is not coded as a multiparty regime.

14 This variable does not include information on unsuccessful challenges to change or remove executive term limits.

15 For example, in Tanzania, terms are five years but the term limit spell is ten (2 terms times 5 years).

16 There are only two cases that fall into this category: Burundi 1993 and Liberia 1997. The events that ended multipartyism in these cases occur well in advance of any likely attempts to change the term limit rules. For example, in Burundi the term-spell was due to end in 2003 but multipartyism ended in 1994.

17 The vast majority of right-censored term-spells fall into this category. For example, the current termspell in Tanzania lasts until 2015. 


\section{Research design, data, and measures}

We test the effect of aid on democratic development in Africa at two stages of democratization. The first analysis explains transitions to multiparty regimes on a sample of 41 countries. The second analysis tests the effect of aid on democratic consolidation using four different operationalizations of democratic consolidation with sample sizes that vary depending on the definition of democratic consolidation. These include multipartyism failure (42 countries), fairness failure (30 countries), incumbent turnover (38 countries), and term limit failure (28 countries). The temporal domain for the analysis is 1989 to 2008 for the first measure and 1991 to 2008 for the latter four.

\subsection{Foreign aid}

For data on aid flows we consult the AidData project, which covers both bilateral and multilateral donor activities. 18 AidData provides information about aid transactions at the project-level.19 We use commitment amounts for our analysis. 20

Second, we aggregate the project information to obtain data on sector aid flows where one row of the data corresponds to the total amount of assistance committed by all donors to a specific sector of an aid-receiving country in a given year. The sector coding scheme assigns one dominant purpose code to the project.21 Democracy assistance has different purposes and different delivery modalities. For instance, we code as democracy assistance projects that directly target economic and development policy/planning such as e.g. fiscal and monetary policy and planning, institutional capacity building, as well as development planning for structural reforms. Democracy and governance aid also finances tax assessment procedures, legal and judicial development, constitutional development, and crime prevention. Donors use democracy aid to support government administration by helping finance civil service reform or government infrastructure. Finally, democracy and governance aid is also directed at strengthening civil society by supporting community participation and development, cooperatives, grass-roots organizations, human rights groups and women's equality institutions, only to name the most prominent civil society groups. 22

18 The AidData project draws on information provided through the OECD’s Creditor Reporting System (CRS). It augments the conventional OECD data by incorporating aid transfers from non-traditional, non-DAC donors, which include e.g. Czech Republic, Slovenia, and Saudi Arabia.

19 The project-level character of the data implies that one row of the data set corresponds to a donor entity committing a certain amount of assistance, measured in constant 2000 US\$, to a recipient country in a given year for a specific project. For the purpose of this study, we aggregate the projectlevel data at the recipient-year level to the highest level to obtain data on total aid flows where one row of the data corresponds to the total amount of assistance committed by all donor entities to a recipient country in a given year.

20 Information on disbursements is much less complete than data on commitments. In PLAID 1.9.2 the commitment field is populated 99.2 per cent of the time, while the disbursement field is populated only 48.6 per cent of the time.

21 We identify the following eleven sector categories, including aid for the social sector, democracy, economic infrastructure and services, domestic production, environment, commodity aid, debt relief, budget support, emergency relief and reconstruction, donor administrative costs, and refugee assistance in donor countries.

22 Table A5 in the Appendix lists the distinct purposes for democracy and governance aid as coded by AidData (2010). 
As is evident in the different purposes of this aid sector, democracy and governance aid is expected to affect democratization through two different channels: to the extent that democratic consolidation depends on state capacity, donors directly invest in state institutions. In contrast, aid for civil society directly goes to non-state actors, thus pressing for bottom-up democratic consolidation processes. Figure 3 offers a breakdown of democracy and governance aid by type of recipient. The top panel of Figure 3 shows the share of democracy aid earmarked to strengthen public institutions. The bottom panel shows the share of democracy assistance directed at civil society building. While both democracy and governance aid channels demonstrate volatility in flows over time, a clear pattern emerges: the vast majority of democracy aid is directed at strengthening public institutions, reaching over 90 per cent in the 1990s and never falling below 80 per cent. Civil society aid, on the other hand, never reaches more than 20 per cent in the period under observation.

Figure 3: Democracy aid channels to SSA
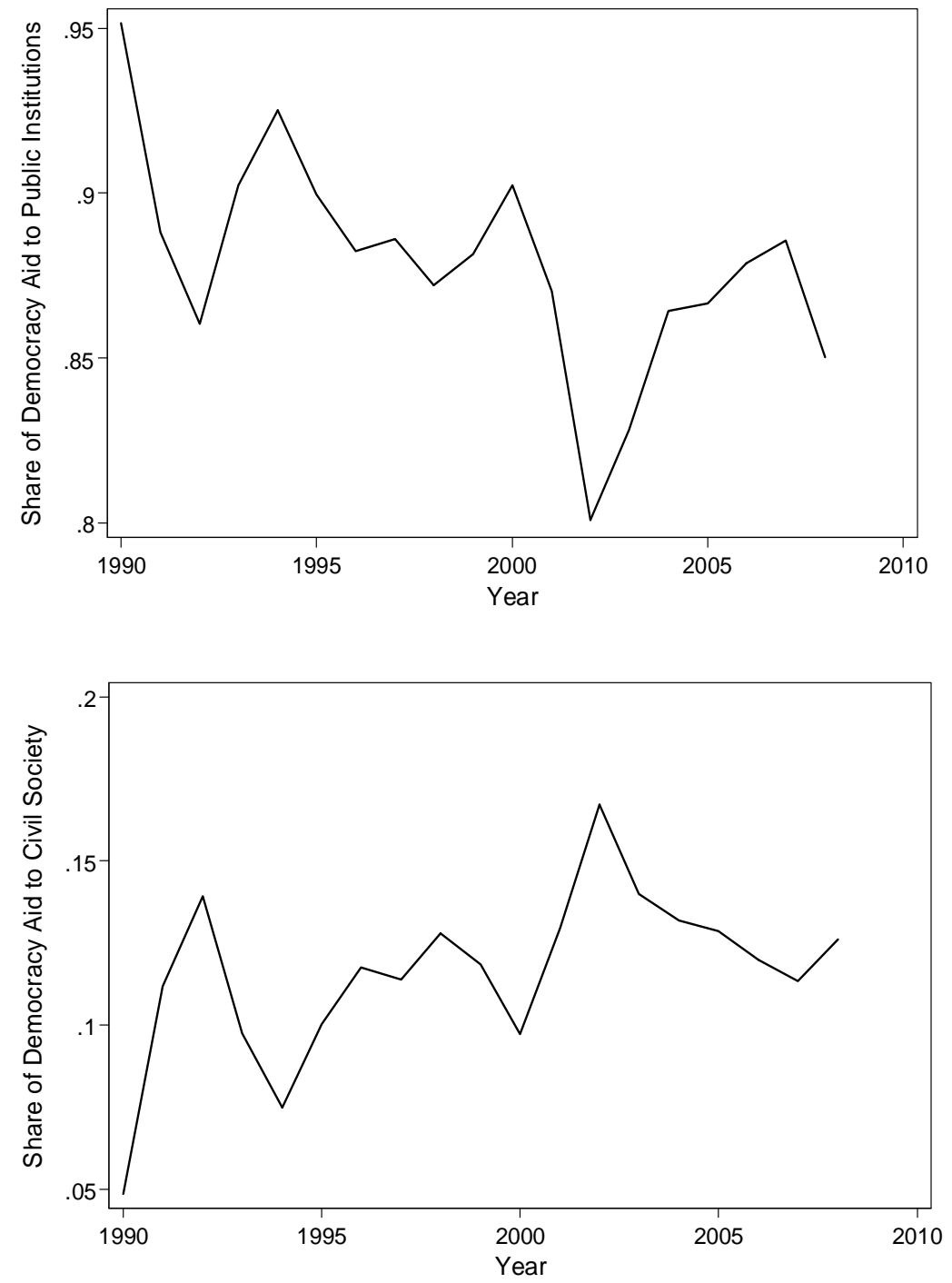

Note: Upper panel is share of democracy aid directed at public institutions; lower panel is share of democracy aid directed at civil society. Shares are two-year ( $t, t-1)$ moving averages of yearly shares in constant dollars: $\frac{\text { GovtDemocracyAid }}{\text { AllDemocracyAid }}$ and $\frac{\text { CivilSocietyAid }}{\text { AllDemocracyAid }}$.

Sources: AidData.org, WDI (2010), and authors' calculations. 
In the empirical analysis, we operationalize the aid data using logged per capita lagged four-year moving average.23 The time series for smaller categories of aid, such as democracy and governance aid, show large variation from year to year. The purpose of using a four-year moving average is to smooth these trends and better captures aid inflows over the prior period. We lag this variable to ensure the direction of causation runs from aid to consolidation. Finally, the log helps ensure that large outliers are not responsible for the main findings.

\subsection{Institutional legacy}

Earlier we discussed how the institutional legacy of neo-patrimonialsim may influence the relationship between foreign assistance and democratic consolidation. To measures this concept, we propose two related variables. First, we calculate the share of years from independence through 1989 in which the country had an elected party in the legislature. This measure of party institutionalization picks up variation in the longevity of a dominant party. Countries with dominant (and single-party) regimes through 1989 have a 100 per cent share, for example Botswana, Gabon, Kenya, Senegal, and Tanzania. Countries that score low on this measure did not have institutionalized parties for long periods of time, for example Burundi, Equatorial Guinea, Nigeria, and Uganda. Figure A1 in the Appendix shows the values for this measure for all countries. 24

Party legacy captures the extent to which incumbents have historically used political parties to deal with political dissent and project formal political authority. The validity of this measure rests on the assumption that rulers who were not sufficiently institutionalized to form a support party and house it in an elected legislature, were less able to project formal political authority over their territory. Note that this variable is not a measure of multipartyism (which was rare prior to 1990) or the absence of rubberstamp institutions.

The second measure is the share of years from independence through 1989 in which a personalist dictator ruled, as coded by Geddes et al. (2012). This variable is intended to capture concepts such as whether the leader has control over military appointments and whether the ruling party preceded the leader or was created by the ruler. There is a fair amount of overlap in these measures because many countries' dominant parties did not suffer from personalist rule, at least as coded in this data set. However there are a handful of countries with long-lived and established parties, such as Gabon and Malawi, which score high on the prior personalism index. Figure A2 in the Appendix shows the value for this measure. 25

23 Precisely, aid is operationalized as $\ln \left(\left(A_{t-1}+A_{t-2}+A_{t-3}+A_{t-4}\right) / 4\right)$ where $A$ is aid per capita in constant dollars. We obtain similar results with 2-year and 3-year lagged moving averages.

24 We assign Eritrea the same value as Ethiopia.

25 Both of these measures only include information prior to 1990 and thus predate the temporal domain of the subsequent analysis. Because prior institutionalization is measured using historical data, we treat this variable as exogenous - or causally prior-to the process of democratic consolidation in the two decades following the end of the Cold War. Geddes et al. (2012) do not code small population countries, such as Comoros and São Tomé or those that were not internationally recognized independent states, such as Namibia prior to 1990. These countries have missing values for this variable. 


\subsection{Estimation}

To model the dependent variables, we adopt a survival approach that accounts for time dependence in the data (Carter and Signorino 2010). This method models the probability that a particular event-such as multiparty failure or incumbent turnoveroccurs in a given year while accounting for the fact that the time since the event previously occurred varies by year. For example, the risk of multiparty failure may be lower if multipartyism has survived for 15 years as opposed to having survived only three years for a particular country-year observation. That is, the failure risk may be greater for Malawi in 1997 than in 2007 simply because multipartyism is 'younger' in 1997 than a decade later.

We employ a random-effects probit model to help address unit heterogeneity (Wilson et al. 2007). This method helps account for factors that we cannot measure but that are different for each country. The main control variables that we include in the analysis are: GDP per capita (log), population (log), level of urbanization, an indicator variable for civil war in the past three years, a variable measuring participation in an IMF adjustment programme in the past two years and a linear time trend. 26 To model transitions to multipartyism, we also include control variables for economic growth (lagged two-year moving average) and neighbour democracy.27 For the analysis of multipartyism and fairness, we also include a control for election year. The sample for incumbent turnover is defined by election year. The models for turnover and term limits include controls for: duration of multiparty regime, and opposition strength in the legislature. 28

\section{Results}

We report the results in table format throughout, but concentrate on the interpretation of the main substantive findings in graphs.

\subsection{Transitions to multiparty regimes}

First we examine the relationship between foreign aid and transitions to multipartyism. If foreign aid can buy liberalizing political reform, the exchange of aid for reform should be more likely when conditionality is enforceable and where the political costs of that reform are relatively low. Aid conditionality is more likely to be enforceable

26 We experimented with other control variables including change in urbanization, higher order polynomials for the time trend and duration dependence and economic growth. None of these controls changed the substantive results and did not improve model fit. In the spirit of parsimony, we dropped them from the reported results. Economic and population data are from the Penn World Tables (version 7.0); data for urbanization comes from the World Development Indictators (2010); and data for civil war is from Gleditsch et al. (2002). IMF data from Dreher (2006). The IMF variable is a lagged two-year moving average for the sum of two binary indicators of IMF programme participation (Structural Adjustment Facility Arrangement and Poverty Reduction and Growth Facility Arrangement) for at least 5 months in a given year.

27 Neighbour democracy is the share of countries with capital cities within $4000 \mathrm{~km}$ of the target country capital city that are democracies. Binary democracy indicator is from Cheibub et al. (2010).

28 Opposition strength is measured as the ratio of seats for the largest opposition party relative to the seats for the incumbent party. Data is from Thorsten et al. (2001), with missing values filled in with information on São Tomé and Principe and Seychelles from African Elections Database (2011). 
during the post-Cold War period when the Soviet influence no longer served as a rival to Western donor influence (Crawford 1997; Dunning 2004; Wright 2009; Bermeo 2011). Thus the sample begins in 1989. The political cost of liberalizing reforms is also likely to vary by size and depth of the support coalition backing the incumbent regimes. When this coalition is broad and deep, political reform is less costly to the incumbent because he and his elite supporters are more likely to retain some claim on power even after liberalization. Following the logic that military regimes typically have smaller and shallower support coalitions than party-based regimes, we examine whether the effect of aid varies by type of incumbent regime, using a dummy variable for military ruler as a proxy for high political costs of liberalizing reform (Wright 2009).29

Table 1: Transitions to multiparty regime

\begin{tabular}{lccc}
\hline & $(1)$ & $(2)$ & $(3)$ \\
\hline Democracy aid & -0.299 & -0.105 & -0.250 \\
Economic aid & $(0.21)$ & $(0.34)$ & $(0.22)$ \\
& $0.278^{\star}$ & 0.286 & $0.659^{\star \star}$ \\
Military*Democracy aid & $(0.17)$ & $(0.17)$ & $(0.25)$ \\
Military*Economic aid & & -0.328 & \\
& & $(0.43)$ & \\
\hline Log GDP per capita & & & $-0.616^{\star \star}$ \\
& & & $(0.27)$ \\
Urban & -0.124 & -0.150 & -0.337 \\
Civil war & $(0.17)$ & $(0.19)$ & $(0.21)$ \\
Economic growth & 0.001 & 0.001 & 0.001 \\
& $(0.01)$ & $(0.01)$ & $(0.01)$ \\
IMF agreement & -0.345 & -0.363 & -0.393 \\
Neighbour democracy & $(0.23)$ & $(0.24)$ & $(0.24)$ \\
Military rule & -0.002 & -0.001 & -0.002 \\
& $(0.02)$ & $(0.02)$ & $(0.02)$ \\
Log likelihood & 0.069 & 0.059 & 0.094 \\
\hline
\end{tabular}

Notes: * $p<0.10 ; * * p<0.05$. Dependent variable is a binary indicator of transition to multipartyism. Random effects probit with standard errors in parentheses. Regime duration, calendar time, and constant included but not reported. 313 observations in 41 countries from 1989-2008.

Source: Authors' calculations based on data listed in the text.

29 All observations in the sample are coded as non-democracy by Cheibub et al. (2010) on 1 January of the observation year. 
Table 1 reports the results. The first model includes all the variables but no interaction terms. Next we include an interaction between military ruler and democracy aid, while the third column includes an interaction between military ruler and economic aid. In all specifications, economic aid is correlated with an increased risk of transition to multipartyism, but democracy aid is not.30 This suggests that countries with higher levels of economic aid are more likely to transition to multipartyism-a finding consistent with previous literature (Goldsmith 2001; Dunning 2004; Wright 2009; Bermeo 2011). Further, military rulers are also more likely to transition, again a finding consistent with earlier research (Geddes 2003).31

Finally, the interaction between economic aid and military rule is negative, while the coefficient for economic aid remains positive and statistically significant. This suggests that the positive correlation between economic aid and the likelihood of transition is due to non-military leaders. If military rule is a good proxy for (high) political costs of transition to multipartyism, then this finding is consistent with Wright's (2009) evidence that (total) aid increases the likelihood of transitions to democracy in the post-Cold War period-but only in authoritarian regimes with lower political costs associated with political reform. That is, aid can be persuasive in buying political reform when the costs of that reform are relatively low.

In this analysis, we control for factors associated with economic crisis, such as participation in an IMF stabilization programme and economic growth, to account for the possibility that the costs of not reforming may be particularly high during these periods. In unreported results, we find that IMF participation strengthens the main empirical relationship between economic aid and multiparty transitions in non-military regimes, though the finding still exists during periods of relative economic health.

Figure 4 shows the substantive effect of the main result for economic aid. 32 In military regimes, economic aid and the risk of transition to multipartyism are not correlated. In non-military regimes, however, there is a strong positive association. At low aid levels, the likelihood of transition is less than two per cent, rising to over ten per cent at high aid levels.

In short, we find that economic aid-but not democracy aid-is associated with an increased probability of multiparty transition, but only in non-military regimes. If military rule is a useful proxy for the (higher) costs of political reform, we can interpret these results to suggest that the exchange of aid for political reform may be more attractive when the costs of losing power are relatively low, for two reasons. First, for

30 While we find little evidence that democracy aid influences multiparty transitions, these countries attract very little democracy assistance relative to economic aid. The median level of democracy aid in this sample is less than US\$2 per capita while this figure stands at US\$67 per capita for economic aid.

31 To assess whether this empirical finding is simply the result of more aid being given to countries that transition, we conduct a difference of means test for the level of (log) economic aid, by whether country ever transitioned. Only 4 of 41 countries in the sample do not transition at some point. While the transition countries have a higher mean, this difference is not statistically different from zero. Similarly, when we regress mean level of economic aid on the mean value for transition and the mean levels of GDP per capita and population (both logs), there is no statistically significant relationship between aid and the transition variable. The lack of association between mean aid and the transition variable persists for the sub-sample of 20 countries with little time spent under military rule.

32 Substantive effects estimated using 1000 simulations of the model in Table 1, with all explanatory variables set at their respective mean or median. Calendar year set to 2000. 
many incumbents the transition to multipartyism does not necessarily threaten their hold on power. Second, this transition is typically less costly for non-military incumbents who have strong support coalitions than for military rulers who lack them.

Figure 4: Economic aid and transitions to multipartyism, years: 1989-2008
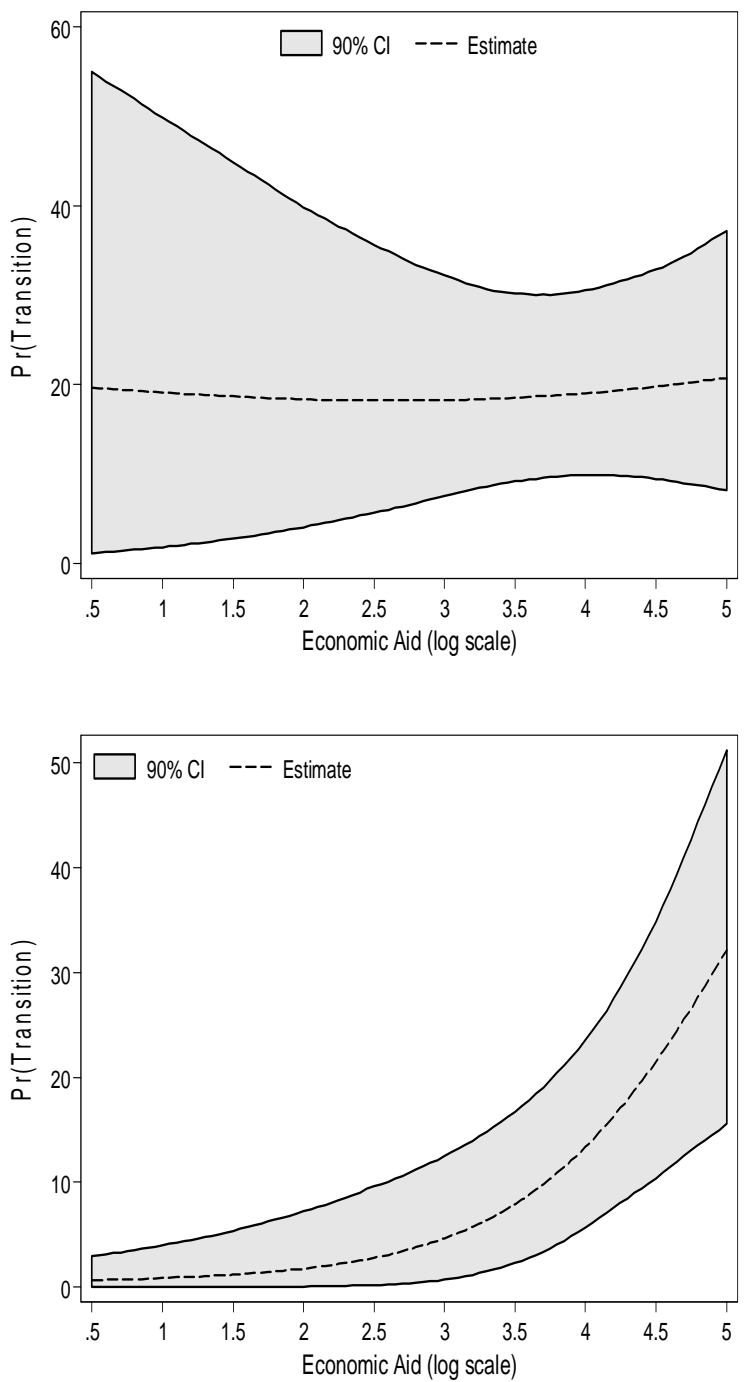

Notes: Risk of transition to multiparty regime on the vertical axis. Upper panel depicts failure risk for a regime headed by a military leader. Lower panel depicts failure risk for regime with a nonmilitary leader. Simulations based on column 3, Table 1.

Source: Authors' calculations based on data listed in the text.

\subsection{Multipartyism and electoral fairness}

The second dependent variable we examine is multiparty failure, reported in Table 2. The average effect of democracy aid is negative and statistically different from zero, 
while the coefficient for economic aid is positive but close to zero (columns 1-3). 33 This suggests that on average democracy aid is associated with a lower likelihood of multiparty failure, while economic aid has little effect. Next, we show how this average effect varies by level of prior institutionalization, reported in columns 4-7.

Table 2: Multiparty failure

\begin{tabular}{|c|c|c|c|c|c|c|c|}
\hline & (1) & (2) & (3) & (4) & (5) & (6) & (7) \\
\hline Democracy aid & $\begin{array}{l}-0.749^{\star \star} \\
(0.36)\end{array}$ & & $\begin{array}{l}-0.705^{\star} \\
(0.39)\end{array}$ & $\begin{array}{l}0.989 \\
(0.84)\end{array}$ & $\begin{array}{l}-0.634 \\
(0.39)\end{array}$ & $\begin{array}{l}-1.405^{\star \star} \\
(0.66)\end{array}$ & $\begin{array}{l}-0.395 \\
(0.37)\end{array}$ \\
\hline Economic aid & & $\begin{array}{l}-0.386 \\
(0.27)\end{array}$ & $\begin{array}{l}-0.096 \\
(0.35)\end{array}$ & $\begin{array}{l}-0.041 \\
(0.34)\end{array}$ & $\begin{array}{l}0.349 \\
(0.66)\end{array}$ & $\begin{array}{l}-0.012 \\
(0.37)\end{array}$ & $\begin{array}{l}0.009 \\
(0.55)\end{array}$ \\
\hline Dem aid*Party legacy & & & & $\begin{array}{c}-2.232^{\star *} \\
(1.08)\end{array}$ & & & \\
\hline Econ aid*Party legacy & & & & & $\begin{array}{l}-0.593 \\
(0.73)\end{array}$ & & \\
\hline $\begin{array}{l}\text { Dem aid*Personalist } \\
\text { legacy }\end{array}$ & & & & & & $\begin{array}{l}1.781^{* *} \\
(0.84)\end{array}$ & \\
\hline $\begin{array}{l}\text { Econ aid*Personalist } \\
\text { legacy }\end{array}$ & & & & & & & $\begin{array}{l}0.133 \\
(0.60) \\
\end{array}$ \\
\hline Party legacy & & & & $\begin{array}{l}2.357^{*} \\
(1.32)\end{array}$ & $\begin{array}{l}2.548 \\
(3.07)\end{array}$ & & \\
\hline Personalist legacy & & & & & & $\begin{array}{c}-1.918^{*} \\
(0.99) \\
\end{array}$ & $\begin{array}{l}-0.538 \\
(2.55) \\
\end{array}$ \\
\hline Log GDP per capita & $\begin{array}{c}-0.645^{\star \star} \\
(0.30)\end{array}$ & $\begin{array}{l}-0.367 \\
(0.24)\end{array}$ & $\begin{array}{c}-0.605^{\star} \\
(0.33)\end{array}$ & $\begin{array}{c}-0.659^{\star \star} \\
(0.28)\end{array}$ & $\begin{array}{c}-0.545^{\star} \\
(0.30)\end{array}$ & $\begin{array}{c}-0.658^{\star \star} \\
(0.32)\end{array}$ & $\begin{array}{c}-0.528^{*} \\
(0.30)\end{array}$ \\
\hline Population & $\begin{array}{c}-0.451^{\star *} \\
(0.19)\end{array}$ & $\begin{array}{c}- \\
0.378^{\star *} \\
(0.16)\end{array}$ & $\begin{array}{c}-0.468^{\star \star} \\
(0.20)\end{array}$ & $\begin{array}{c}-0.455^{\star \star} \\
(0.16)\end{array}$ & $\begin{array}{c}-0.448^{\star \star} \\
(0.19)\end{array}$ & $\begin{array}{r}-0.621^{\star \star} \\
(0.21)\end{array}$ & $\begin{array}{r}-0.615^{\star \star} \\
(0.20)\end{array}$ \\
\hline Election year & $\begin{array}{l}-0.153 \\
(0.33)\end{array}$ & $\begin{array}{l}-0.109 \\
(0.31)\end{array}$ & $\begin{array}{l}-0.152 \\
(0.33)\end{array}$ & $\begin{array}{l}-0.157 \\
(0.33)\end{array}$ & $\begin{array}{l}-0.136 \\
(0.33)\end{array}$ & $\begin{array}{l}-0.227 \\
(0.37)\end{array}$ & $\begin{array}{l}-0.238 \\
(0.36)\end{array}$ \\
\hline Civil war & $\begin{array}{l}0.617 \\
(0.39)\end{array}$ & $\begin{array}{l}0.569^{\star} \\
(0.33)\end{array}$ & $\begin{array}{l}0.601 \\
(0.39)\end{array}$ & $\begin{array}{l}0.720^{\star *} \\
(0.35)\end{array}$ & $\begin{array}{l}0.684^{*} \\
(0.38)\end{array}$ & $\begin{array}{l}0.858^{* *} \\
(0.36)\end{array}$ & $\begin{array}{c}0.798^{\star *} \\
(0.35)\end{array}$ \\
\hline Urban & $\begin{array}{l}0.007 \\
(0.02)\end{array}$ & $\begin{array}{l}0.006 \\
(0.01)\end{array}$ & $\begin{array}{l}0.007 \\
(0.02)\end{array}$ & $\begin{array}{l}0.007 \\
(0.02)\end{array}$ & $\begin{array}{l}0.005 \\
(0.02)\end{array}$ & $\begin{array}{l}0.006 \\
(0.02)\end{array}$ & $\begin{array}{l}0.005 \\
(0.02)\end{array}$ \\
\hline IMF agreement & $\begin{array}{l}0.630^{*} \\
(0.38) \\
\end{array}$ & $\begin{array}{l}0.619^{*} \\
(0.37) \\
\end{array}$ & $\begin{array}{l}0.673 \\
(0.41) \\
\end{array}$ & $\begin{array}{l}0.566 \\
(0.39) \\
\end{array}$ & $\begin{array}{l}0.650 \\
(0.41) \\
\end{array}$ & $\begin{array}{l}0.591 \\
(0.42) \\
\end{array}$ & $\begin{array}{l}0.527 \\
(0.40) \\
\end{array}$ \\
\hline Log likelihood & -51.5 & -53.5 & -51.5 & -49.1 & -51.1 & -42.7 & $\begin{array}{c}-45.3 \\
483\end{array}$ \\
\hline
\end{tabular}

Notes: ${ }^{\star} p<0.10 ;{ }^{*} p<0.05$. Random effects probit with standard errors in parentheses. Time trend, duration time, and constant included but not reported. 42 (36 in columns 6-7) countries from 1991-2008.

Source: Authors' calculations based on data listed in the text.

33 To ensure that the result for democracy aid is not due to the fact that failing countries receive less democracy aid, on average, we conduct a difference of means test. The results show that countries with multiparty failure (less democratic) actually receive more aid on average than those which do not, though this difference is not statistically different from zero. Controlling for GDP per capita and population, those that fail still receive slightly more democracy aid. 
Figure 5 depicts the predicted probability of multiparty failure at high and low levels of democracy aid. The top panel assesses the aid effect by prior party institutionalization, where high party institutionalization is set at 100 per cent (e.g. Senegal) and low party institutionalization is set at 40 per cent (e.g. Nigeria). At low party institutionalization, a two standard deviation increase in democracy aid is correlated with an increase in the failure risk, from 1.2 per cent to 1.7 per cent. However, this increase is not statistically different from zero. In multiparty regimes with a high level of prior party institutionalization, democracy aid is associated with a statistically significant decrease in the failure risk, which falls from 2.3 per cent to 0.1 per cent as aid increases two standard deviations.

Figure 5: Democracy aid and multi-partyism failure, by institutional legacies, years: 1991-2008
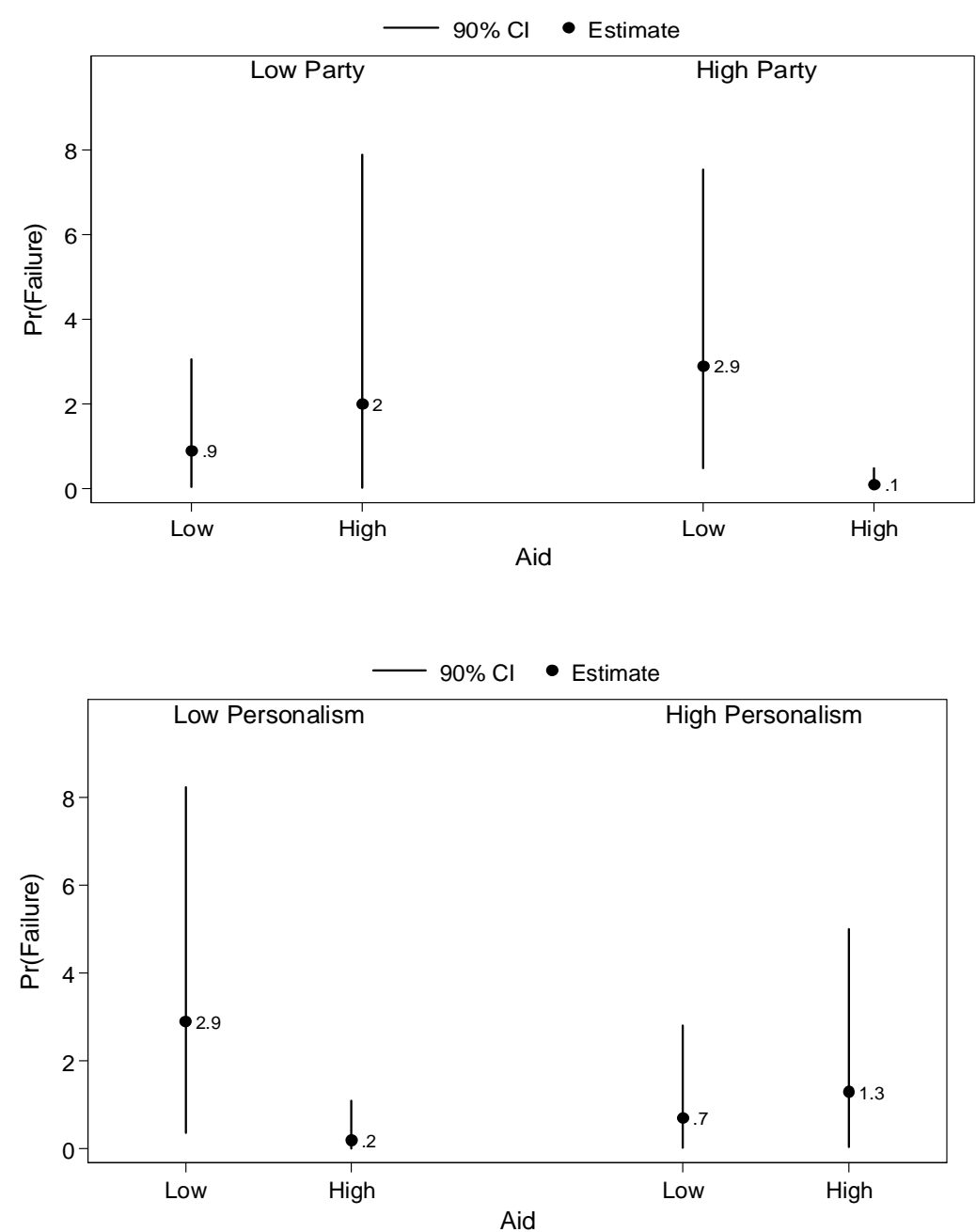

Notes: Risk of multiparty failure on the vertical axis. High (Low) aid is one standard-deviation above (below) the in-sample mean. Upper panel depicts failure risk by pre-1990 share of years with at least one party in an elected legislature: 40\% (e.g. Nigeria) and 100\% (e.g. Senegal). Lower panel depicts failure risk by pre-1990 share of years under personalist rule: $0 \%$ (e.g. Botswana) and 90\% (e.g. Burkina Faso). Results based on models in columns 4 and 6, Table 2.

Sources: Authors' calculations based on data listed in the text. 
We find a similar pattern for prior personalism in the bottom panel of Figure 5.34 Where the country has never been ruled by a personalist dictator, democracy aid is associated with a drop in multiparty failure risk ( 2.3 per cent to 0.2 per cent), while the level of democracy aid is correlated with a small increase in failure risk in countries with a high score on the personalism index (90 per cent).

Figure 6: Economic aid and multipartyism failure, by institutional legacies, years: 1990-2008
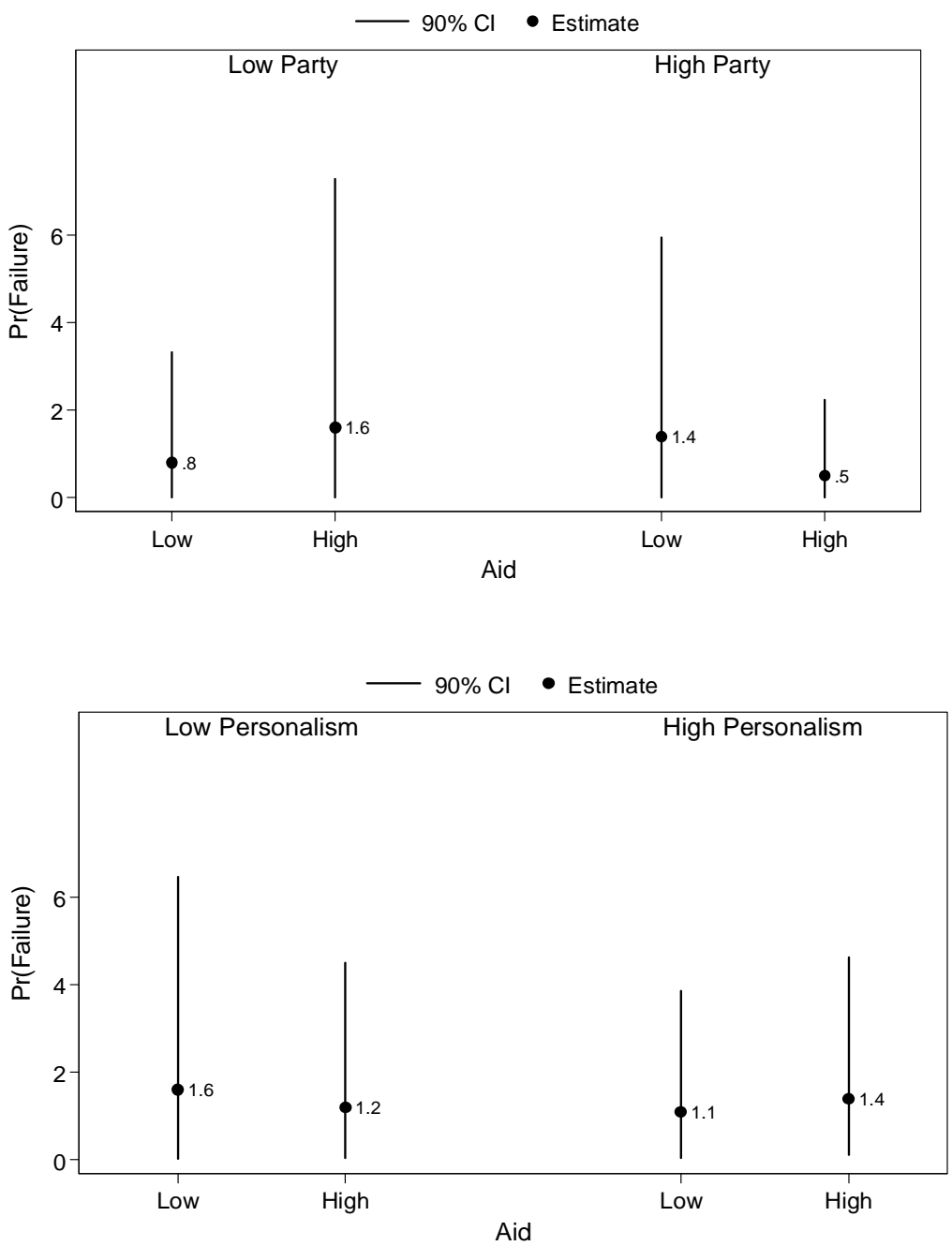

Notes: Risk of multiparty failure on the vertical axis. High (Low) aid is one standard-deviation above (below) the in-sample mean. Upper panel depicts failure risk by pre-1990 share of years with at least one party in an elected legislature: 40\% (e.g. Nigeria) and 100\% (e.g. Senegal). Lower panel depicts failure risk by pre-1990 share of years under personalist rule: $0 \%$ (e.g. Botswana) and 90\% (e.g. Burkina Faso). Results based on models in columns 5 and 7, Table 2.

Source: Authors' calculations based on data listed in the text.

34 These results exclude small population countries and those that were not independent states prior to 1990: Cape Verde, Comoros, Djibouti, Equatorial Guinea, Eritrea, Namibia, São Tomé and Principe, and Seychelles. Small states are not coded in the Geddes et al. (2012) dataset. 
Figure 6 depicts the relationship between economic aid and the risk of multiparty failure. For countries with a strong party legacy, the results suggest that economic assistance is associated with a lower risk of failure, though this difference (0.9 to 0.5) is not statistically different from zero. For personalist legacies, there appears to be little difference in the relationship between aid and multiparty failure between countries with strong and weak personalist legacies.

The results for democracy aid suggest that the institutional legacy of the country matters. Whether we measure this legacy as personalism or party institutionalization, the results are consistent: democracy aid is associated with a lower risk of multiparty failure in countries with a low prior personalism and strong party institutionalization. This should not be surprising given the large overlap in the grouping of countries along these dimensions. There is, however, little evidence that economic aid is associated with multiparty failure, regardless of institutional legacy.

One concern that arises in the analysis of multiparty failure is the inclusion of nominally multiparty electoral regimes where political competition and participation is severely circumscribed, as is the case with Guinea under Conte's rule and Uganda during Museveni's time in power. We thus examine the failure of multipartyism and political fairness, as measured by the combined Freedom House scores. Many of the same events that are coded as failure in the previous analysis are again coded as failure here, such as military coups. In addition, failure in this analysis can comprise a marked decrease in electoral fairness, short of ending multiparty politics. For example, Zambia 1996 is coded as fairness failure, but multipartyism continues so it is not coded as failure in the analysis of multiparty regime survival.

Table 3 presents the main results for aid and electoral fairness. The patterns suggested by these results are consistent with the findings for multiparty failure: democracy aid is associated with a lower risk of fairness failure, while economic aid is not. Further, the institutional legacy of the countries again conditions the finding for democracy aid. In countries with low personalism and high party institutionalization, the democracy aid result is considerably stronger.

So far, two patterns have emerged from the analysis of multipartyism and electoral fairness failure. First, the risk of these anti-democratic events occurring is lower in countries with higher levels of democracy aid, suggesting a possible positive effect of democracy assistance on consolidation. This finding is strongest for countries with 'good' institutional legacies: high party legacy and low prior personalism. Second, economic aid appears to work in the opposite direction: countries with high levels of this type of assistance are more likely to experience multiparty failure. Though none of the results for economic aid achieve conventional statistical significance, they nonetheless indicate a very different pattern of correlations with failure events than democracy aid. 
Table 3: Electoral fairness failure

\begin{tabular}{|c|c|c|c|c|c|c|}
\hline & (1) & (2) & (3) & (4) & (5) & (6) \\
\hline Democracy aid & $\begin{array}{c}-0.768^{\star \star} \\
(0.36)\end{array}$ & $\begin{array}{l}0.971 \\
(1.28)\end{array}$ & $\begin{array}{c}-0.756^{\star \star} \\
(0.37)\end{array}$ & $\begin{array}{l}-0.613 \\
(0.41)\end{array}$ & $\begin{array}{c}-0.901^{*} \\
(0.53)\end{array}$ & $\begin{array}{l}-0.596 \\
(0.41)\end{array}$ \\
\hline Economic aid & $\begin{array}{l}0.396 \\
(0.34)\end{array}$ & $\begin{array}{l}0.530 \\
(0.42)\end{array}$ & $\begin{array}{l}0.529 \\
(0.76)\end{array}$ & $\begin{array}{l}0.513 \\
(0.36)\end{array}$ & $\begin{array}{l}0.482 \\
(0.36)\end{array}$ & $\begin{array}{l}0.728 \\
(0.53)\end{array}$ \\
\hline Dem aid*Party legacy & & $\begin{array}{l}-2.328 \\
(1.72)\end{array}$ & & & & \\
\hline Econ aid*Party legacy & & & $\begin{array}{l}-0.168 \\
(0.85)\end{array}$ & & & \\
\hline Dem aid*Personalist legacy & & & & & $\begin{array}{l}0.637 \\
(0.71)\end{array}$ & \\
\hline Econ aid*Personalist legacy & & & & & & $\begin{array}{r}-0.417 \\
(0.69) \\
\end{array}$ \\
\hline Party legacy & $\begin{array}{l}-0.073 \\
(0.67)\end{array}$ & $\begin{array}{l}2.260 \\
(1.86)\end{array}$ & $\begin{array}{l}0.584 \\
(3.38)\end{array}$ & & & \\
\hline Personalist legacy & & & & $\begin{array}{l}-0.018 \\
(0.42) \\
\end{array}$ & $\begin{array}{l}-0.875 \\
(1.03) \\
\end{array}$ & $\begin{array}{l}1.816 \\
(3.08) \\
\end{array}$ \\
\hline GDP per capita & $\begin{array}{l}-0.501^{*} \\
(0.26)\end{array}$ & $\begin{array}{c}-0.691^{*} \\
(0.37)\end{array}$ & $\begin{array}{c}-0.497^{*} \\
(0.25)\end{array}$ & $\begin{array}{l}-0.319 \\
(0.28)\end{array}$ & $\begin{array}{l}-0.348 \\
(0.28)\end{array}$ & $\begin{array}{l}-0.205 \\
(0.34)\end{array}$ \\
\hline Population & $\begin{array}{l}0.012 \\
(0.12)\end{array}$ & $\begin{array}{l}0.050 \\
(0.15)\end{array}$ & $\begin{array}{l}0.013 \\
(0.13)\end{array}$ & $\begin{array}{l}-0.122 \\
(0.16)\end{array}$ & $\begin{array}{l}-0.134 \\
(0.16)\end{array}$ & $\begin{array}{l}-0.106 \\
(0.16)\end{array}$ \\
\hline Election year & $\begin{array}{l}0.119 \\
(0.31)\end{array}$ & $\begin{array}{l}0.175 \\
(0.34)\end{array}$ & $\begin{array}{l}0.124 \\
(0.31)\end{array}$ & $\begin{array}{l}0.024 \\
(0.35)\end{array}$ & $\begin{array}{l}0.057 \\
(0.35)\end{array}$ & $\begin{array}{l}0.016 \\
(0.35)\end{array}$ \\
\hline Civil war & $\begin{array}{l}0.330 \\
(0.60)\end{array}$ & $\begin{array}{l}0.236 \\
(0.68)\end{array}$ & $\begin{array}{l}0.346 \\
(0.61)\end{array}$ & $\begin{array}{l}0.506 \\
(0.61)\end{array}$ & $\begin{array}{l}0.393 \\
(0.63)\end{array}$ & $\begin{array}{l}0.617 \\
(0.65)\end{array}$ \\
\hline Urban & $\begin{array}{l}0.024^{*} \\
(0.01)\end{array}$ & $\begin{array}{l}0.035^{*} \\
(0.02)\end{array}$ & $\begin{array}{l}0.025^{*} \\
(0.01)\end{array}$ & $\begin{array}{l}0.022 \\
(0.01)\end{array}$ & $\begin{array}{l}0.022 \\
(0.01)\end{array}$ & $\begin{array}{l}0.021 \\
(0.01)\end{array}$ \\
\hline IMF agreement & $\begin{array}{l}0.054 \\
(0.35) \\
\end{array}$ & $\begin{array}{l}-0.100 \\
(0.40) \\
\end{array}$ & $\begin{array}{l}0.039 \\
(0.36) \\
\end{array}$ & $\begin{array}{l}-0.108 \\
(0.36) \\
\end{array}$ & $\begin{array}{l}-0.059 \\
(0.36) \\
\end{array}$ & $\begin{array}{l}-0.116 \\
(0.36) \\
\end{array}$ \\
\hline Log likelihood & -51.2 & -49.8 & -51.2 & -45.2 & -44.1 & -45.0 \\
\hline Observations & 337 & 337 & 337 & 266 & 266 & 266 \\
\hline
\end{tabular}

Notes: ${ }^{*} p<0.10 ;{ }^{* *} p<0.05$. Random effects probit with standard errors in parentheses. Time trend, duration time, and constant included but not reported. 30 (25 in columns 4-6) countries from 1991-2008.

Source: Authors' calculations based on data listed in the text.

\subsection{Incumbent turnover and term limit violations}

Next we examine measures of democratic consolidation that may be quite different from multiparty and fairness failure events because they represent direct threats to the incumbent, whereas the previous measures frequently constitute continued incumbent rule. While we found evidence that institutional legacy influences the relationship between foreign aid and risk of multiparty transitions and multiparty collapse, we found no evidence that these factors shape the relationship between aid and the two measures we examine in this section: incumbent turnover and term limit violations. Instead, we show that the strength of the opposition may matter, especially for economic aid. 
Table 4: Incumbent turnover

\begin{tabular}{lcccccc}
\hline & $(1)$ & $(2)$ & $(3)$ & $(4)$ & $(5)$ & $(6)$ \\
\hline Democracy aid & 0.285 & & $0.855^{\star}$ & $1.121^{*}$ & $1.482^{\star}$ & 0.954 \\
& $(0.30)$ & & $(0.48)$ & $(0.64)$ & $(0.76)$ & $(0.61)$ \\
Economic aid & & -0.205 & -0.708 & -1.047 & -1.094 & $-1.686^{*}$ \\
& & $(0.34)$ & $(0.45)$ & $(0.75)$ & $(0.72)$ & $(0.97)$ \\
Dem aid*Opp strength & & & & & -0.981 & \\
& & & & & $(1.55)$ & \\
Econ aid*Opp strength & & & & & & $2.835^{\star}$ \\
& & & & & & $(1.46)$ \\
\hline Opposition strength & 0.044 & 0.106 & -0.192 & -0.305 & 1.052 & $-12.171^{\star}$ \\
& $(0.69)$ & $(0.68)$ & $(0.76)$ & $(0.80)$ & $(2.34)$ & $(6.38)$ \\
Urban & & & & 0.025 & 0.027 & 0.022 \\
& & & & $(0.03)$ & $(0.03)$ & $(0.03)$ \\
GDP per capita & & & & -0.239 & -0.303 & -0.160 \\
& & & & $(0.50)$ & $(0.52)$ & $(0.53)$ \\
IMF agreement & & & & -0.223 & -0.269 & 0.049 \\
& & & & $(0.58)$ & $(0.57)$ & $(0.59)$ \\
\hline Log likelihood & -22.1 & -22.2 & -21.1 & -20.6 & -20.5 & -19.7 \\
\hline
\end{tabular}

Notes: * $p<0.10$; ${ }^{*} p<0.05$. Executive elections only. Random effects probit with standard errors in parentheses. Time trend, duration time, and constant included but not reported. 58 observations in 30 countries from 1991-2008.

Source: Authors' calculations based on data listed in the text.

First, we discuss results for the average effect of different types of aid on the probability of incumbent turnover during presidential election years. The first two models in Table 4 include only one type of aid at a time, and the results suggest little relationship between either type of aid and incumbent turnover. Once we include both types of aid in the same model in column 3, however, the result suggests that democracy aid is associated with an increased risk of incumbent turnover. 35 This finding is slightly stronger once we control for other factors in column 4. Figure 7 shows that the statistical finding for democracy aid and incumbent turnover is substantively quite strong. Low levels of democracy aid are associated with less than 5 per cent likelihood of turnover, but this figure rises to over twenty per cent at high democracy aid levels.

35 To assess whether this finding is the result of multiparty regimes which experience incumbent turnover receiving more aid than those that do not, we conduct a difference of means test for the 30 countries in the sample. While turnover countries (8) have slightly higher democracy and economic aid levels than non-turnover countries (22), this difference is not statistically different from zero. Controlling for population and GDP per capita, the difference is again not different from zero. 
Figure 7: Foreign aid and incumbent turnover, years: 1991-2008
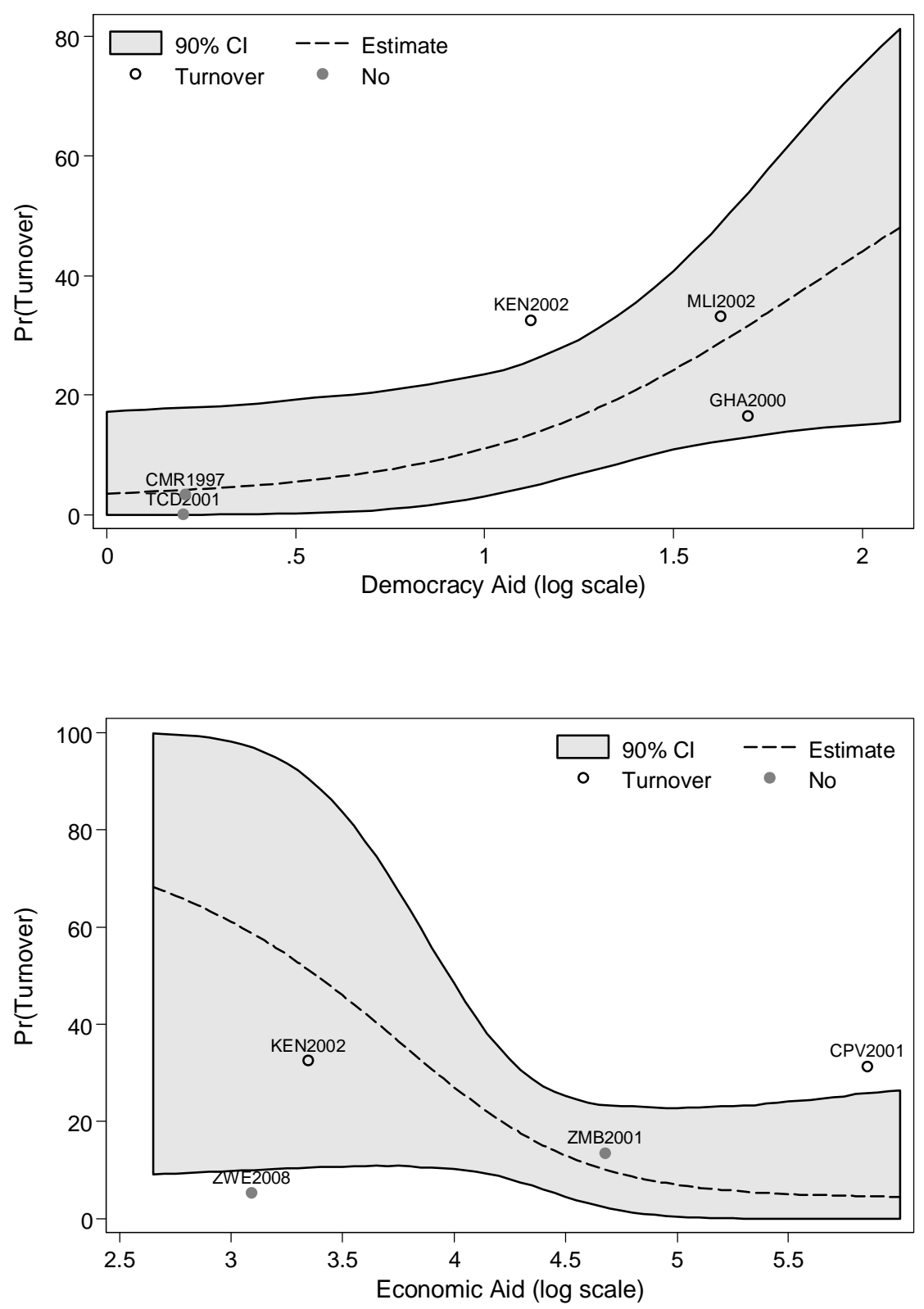

Notes: Estimates and confidence intervals for average predicted probability of incumbent turnover during a multiparty election, for values of aid (log scale). Observations $\equiv 58$; countries $\equiv 30$. Simulations based on model in column 4 , Table 4 .

Source: Authors' calculations based on data listed in the text.

To ensure that the result is not due to the inclusion of any one particular country, we reran the analysis excluding every country, one at a time. The distribution of coefficients for democracy aid indicates that this pattern does not rely on information from one country. The weakest result for democracy aid is observed when we exclude Cape Verde (turnover in 2000), but even excluding this country, we find a large and substantively significant correlation between democracy aid and the risk of incumbent turnover. 
Finally, in the last two columns we interact each type of aid with opposition strength, and find that economic aid is associated with a lower likelihood of turnover when the opposition is weak. This result suggests that economic aid may help keep incumbents in power when they dominate the legislature, but that economic aid is unlikely to prevent incumbent turnover when the opposition has a strong legislative presence.

Opposition legislative strength, at least as we have measured it here, is not highly correlated the measures of institutional legacy (party and personalist legacy). 36 For example, multiparty elections under a weak legislative opposition include relatively institutionalized (i.e. low personalist legacy) countries such as Tanzania (0.11 opposition-incumbent seat ratio in 2000 and 2005) as well as regimes with low levels of institutionalization such as Burkina Faso (0.06 in 1998 and 0.11 in 2005) and Chad (0.08 in 2006). Multiparty elections under strong legislative opposition include Malawi (0.65) and Mozambique (0.85) in the late 1990s and 2000s.

The final measure of consolidation is the violation of term limits. We examine 34 observations where multiparty regimes were at risk of changing term limit rules. For each observation, the term limit rule was either changed before the end of the term or the term limit was reached and respected. We exclude right-censored observations where the end of the term was not reached either because of a coup or the calendar date for the end of the limited term is later than 2010. The covariates are measured for the observation year when either the term limit was violated or the limited term was reached and not violated.

Table 5 reports the results. We include opposition strength in all the empirical models because it is a strong determinant of term limit violation in this sample, though including this variable does not alter the main finding. In models with and without control variables, democracy aid is associated with a lower risk of term limit violation, while economic aid has no statistical association.

Figure 8 shows the substantive effect of this relationship, based on the model in column 5 of Table 5. The top panel shows how the estimated risk of term limit violation declines as the level of democracy aid increases. At low levels of aid, the risk is over 40 per cent and drops to less than 5 per cent at high aid levels. With only 34 observations we also plot the observed level of democracy aid and the predicted risk of violation. Hollow dots indicate term limit violations, while solid dots indicate no violation. Of the five observations with the lowest democracy aid levels, only one (Nigeria 2007) did not violate term limit rules. Of the observations where the term limit was violated, the highest democracy aid recipient is Namibia (1998)—which falls near the middle of the distribution of democracy aid.

The bottom panel depicts the relationship between economic aid and term limit violations. There is no strong correlation between this type of assistance and the probability of a term limit violation. Again we plot the observed values of economic aid and the predicted risk of violating a term limit, illustrating the same flat pattern.

36 The correlation between opposition strength and party legacy is 0.05 and between opposition strength and personalist legacy is -0.01 . 
Table 5: Term limit violation

\begin{tabular}{|c|c|c|c|c|c|}
\hline & (1) & (2) & (3) & (4) & (5) \\
\hline \multirow[t]{2}{*}{ Democracy aid } & $-0.912^{\star}$ & & $-1.348^{\star}$ & & $-1.392^{*}$ \\
\hline & $(0.48)$ & & $(0.72)$ & & $(0.76)$ \\
\hline \multirow[t]{2}{*}{ Economic aid } & & -0.285 & & -0.579 & 0.060 \\
\hline & & $(0.37)$ & & $(0.56)$ & $(0.59)$ \\
\hline \multirow[t]{2}{*}{ Opposition strength } & $-2.860 \star \star$ & $-3.005^{\star \star}$ & $-2.616^{\star \star}$ & $-2.736^{\star}$ & $-2.608^{\star \star}$ \\
\hline & $(0.91)$ & $(0.92)$ & $(1.31)$ & $(1.42)$ & $(1.30)$ \\
\hline \multirow[t]{2}{*}{ Party duration } & & & -0.062 & -0.034 & -0.062 \\
\hline & & & $(0.06)$ & $(0.04)$ & $(0.06)$ \\
\hline \multirow[t]{2}{*}{ GDP per capita } & & & 0.154 & 0.235 & 0.147 \\
\hline & & & $(0.38)$ & $(0.38)$ & $(0.38)$ \\
\hline \multirow[t]{2}{*}{ Urban } & & & 0.005 & 0.012 & 0.004 \\
\hline & & & $(0.02)$ & $(0.02)$ & $(0.02)$ \\
\hline \multirow[t]{2}{*}{ Civil war } & & & $3.199^{\star *}$ & $3.470^{\star \star}$ & $3.159^{\star \star}$ \\
\hline & & & $(1.14)$ & $(0.97)$ & $(1.24)$ \\
\hline Log likelihood & -16.1 & -17.3 & -12.5 & -13.8 & -12.5 \\
\hline
\end{tabular}

Notes: ${ }^{*} p<0.10 ;{ }^{*} p<0.05$. Random effects probit with standard errors in parentheses. Constant included but not reported. 34 observations in 28 countries from 1991-2008.

Source: Authors' calculations based on data listed in the text.

While these results show a strong relationship between democracy aid and lower risk of term limit violation, we cannot rule out the possibility that this finding is due to the fact that violating countries simply receive less aid than those that do not. A difference means test for the 28 countries in the sample indicates that the 18 countries that do not violate (but that are at risk of violating) receive substantially more democracy aid than the 11 countries where term limit violation occurs. Therefore, the results in Table 5 and Figure 8 should be interpreted with this caveat in mind.

This stands in contrast with the findings reported earlier in the study; in these tests, more democratic countries do not receive substantially more or less foreign aid than less democratic countries. As reported in Table A6, the only statistically significant difference of means test comes from the term limit violation sample. 
Figure 8: Foreign aid and term limit violations, years: 1991-2010
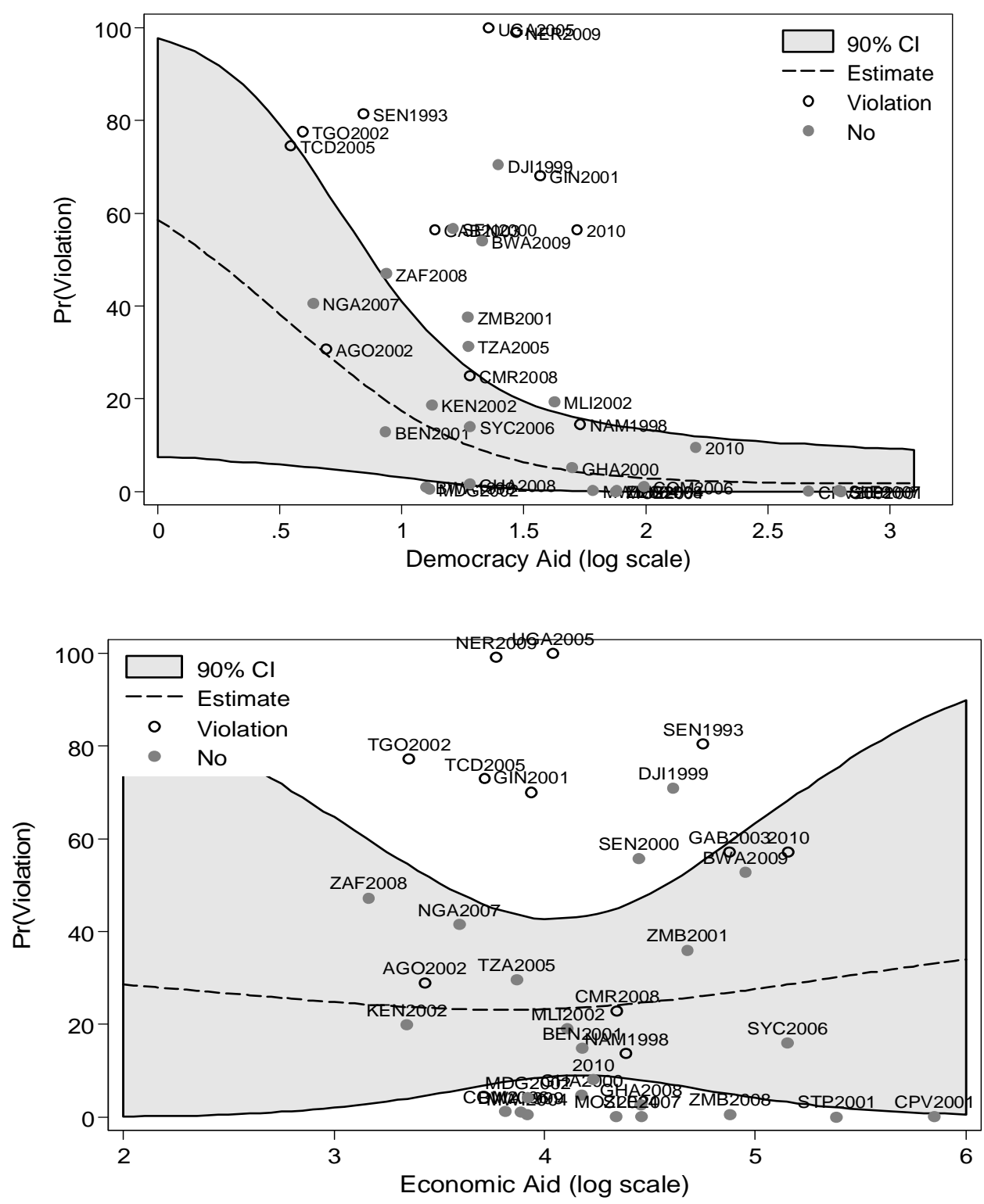

Notes: Estimates and confidence intervals for average predicted probability of term limit violation for values of aid (log scale). Observed aid levels and predicted probability of violation in scatter plot. Observations $=34$; countries $=28$. Simulations based on model 5 , Table 5 .

Source: Authors' calculations based on data listed in the text.

\section{Discussion}

While preliminary, the results from our empirical analysis have produced several insights into the relationship between foreign aid and democratic transition and consolidation in Africa. Democracy and governance aid is consistently associated with consolidation in African democracies, across all four measures of consolidation processes. Equally consistent is the finding that economic aid is statistically unrelated to democratic consolidation — a finding which confirms our working null-hypothesis of 'no 
effect'.37 While donors may only be able to buy relatively cheap reform-such as multiparty elections - through economic aid, they may be successful in promoting democracy through specific democracy projects, which, according to Figure 3, are largely directed at capacity building. If democracy and governance aid and democratic consolidation are indeed related, then it is important to provide a brief ex post discussion that fleshes out the potential causal mechanism. First, democracy assistance may contribute to leveling the political playing field by strengthening public institutions as well as civil society. Incumbents with sufficient capacity to deal with an increasingly robust opposition, as would be the case in countries with a greater degree of prior institutionalization, may not be as threatened by the persistence of multiparty politics or increasingly fair elections as incumbents in countries where dissent and opposition were not sufficiently institutionalized. In these settings, democracy and governance aid that increases opposition strength may increase political uncertainty and threaten democratic practices precisely because they threaten incumbents. Democracy aid might therefore help perpetuate a multiparty system in which strong, institutionalized incumbents remain in power; indeed aid might legitimize and pay for an electoral process they can win.

This explanation, however, is less persuasive for the other two measures of democratic consolidation, incumbent turn-over and the respect for constitutional term limits. We thus offer another potential explanation: democracy assistance may level the electoral playing field and in doing so reduce the stakes of winning and losing. If aid helps institutionalize politics, this should lower the benefits of remaining in power and lower the costs of losing. With institutionalized politics, the benefits of holding office in the current period are lower because controlling the state may not result in as many opportunities for extracting rents. Further, institutionalization that creates fairer electoral politics can lower the costs of losing in the current period by increasing the chances of winning power anew, even after an electoral defeat. The costs of stepping down from power are lower precisely because there will be real opportunities to compete for power in the future. We might think of this mechanism as: democracy assistance helps institutionalize politics by creating a more competitive electoral system, thus reducing incumbency advantage.

To close, we highlight one avenue for future research. While we have disaggregated aid by purpose-economic aid and democracy assistance-we have not addressed variation in channels through which donors delivery aid. OECD donors channel significant amounts of bilateral assistance through non-state development actors, circumventing recipient governments: in 2008, OECD donors committed a total of US\$112 billion and delegated over 30 per cent of the aid, approximately US\$41 billion, for implementation through non-state development actors, which include NGOs, multilaterals, and private contractors (OECD 2010). These non-state actors are hired for specific project delivery and remain accountable to the donors. Knowledge about variation in delivery channels not only begs the question about how they may affect democratic consolidation differently, but it also raises an important selection issue: Do donors employ delivery mechanisms tactically? And if they do, what determines their choice? Dietrich (2011) provides evidence that donors are systematic about selecting the aid delivery channel when it comes to development outcomes, i.e. donors bypass recipient governments in

37 We do find evidence, however, that economic aid is associated with transitions to multipartyism in non-military regimes. 
countries where the probability of aid waste through corrupt public officials and inefficient institutions is high, thus influencing ex ante the channels through which foreign assistance affects aid outcomes.

Whether donors choose the recipient government as their primary implementing partner may also influence an aid-receiving country's prospects for democratic transitions and consolidation. For instance, aid delivered through governments may be more fungible than aid sent through third party actors, thus affecting the share of economic aid available for buying political reform. In our analysis, we have assumed that economic aid flows are fully accessible to recipient governments. Democracy and governance aid, too, can be delivered through both governments and non-state actors. Promoting democracy by directly funding civil society may have very different consequences on democratic consolidation than funding leaders who invest democracy aid in building state institutions. While the former directly strengthens the opposition, the latter may enable leaders to maintain a minimal level of democracy and maintain power, especially in countries with high levels of prior political institutionalization. Finally, does democracy and governance aid delivered to recipient governments primarily flow to those with greatest need for democracy? Or do donors favour non-state development actors in these situations? Answers to these important questions will improve our understanding of how foreign aid influences democratic consolidation.

\section{References}

African Elections Database (2011). Accessed at http://africanelections.tripod.com.

AidData (2011). 'AidData's Sector Coding Scheme.' Accessed at: http://www.aiddata.org/weceem_uploads/_ROOT/File/Coding\%20Scheme/AidData \%20Coding\%20Scheme.pdf

Ake, C. (1996). 'Rethinking African Democracy'. In L. Diamond and M.F. Plattner (eds), The Global Resurgence of Democracy. Baltimore: Johns Hopkins University Press.

Baker, B. (1998). 'The Class of 1990: How Have the Autocratic Leaders of SubSaharan Africa Fared Under Democratisation?’ Third World Quarterly, 19(1):11527.

Baturo, A. (2010). 'The Stakes of Losing Office, Term Limits and Democracy'. British Journal of Political Science, 40(3): 635-62.

Bates, R.R. (1981). Markets and States in Tropical Africa. Berkeley: California University Press.

Bauer, P.T. (1971). Dissent on Development. London: Weidenfield and Nicholson.

Bearce, D, and D. Tirone (2010). 'Foreign Aid Effectiveness and the Strategic Goals of Donor Governments'. Journal of Politics, 72(3): 837-51.

Berlinschi, R. (2010). 'Reputation Concerns in Aid Conditionality'. The Review of International Organizations, 5(4): 433-59. 
Bermeo, S. (2009). 'The Curse of Aid? Re-Examining the Impact of Aid on Regime Change'. Paper presented at the Annual Meeting of the American Political Science Association, Toronto, Canada. Available at: http://tinyurl.com/733ultv.

Bermeo, S. (2011). 'Foreign Aid and Regime Change: A Role for Donor Intent'. World Development, 39(11): 2021-31.

Boix, C., and S. Stokes (2003). 'Endogenous Democratization'. World Politics, 55(4): 517-49.

Bratton, M. (1998). 'Second Elections in Africa'. Journal of Democracy, 9(3): 51-66.

Bratton, M., and N. van de Walle (1997). Democratic Experiments in Africa. Cambridge: Cambridge University Press.

Brautigam, D. (2000). Aid, Dependence, and Governance. Stockholm: Almqvist and Wiksell.

Brautigam, D., and S. Knack (2004). 'Foreign Aid, Institutions, and Governance in SubSaharan Africa'. Economic Development and Cultural Change, 52(2): 255-85.

Bueno de Mesquita, B., and A. Smith (2010). 'Leader Survival, Revolutions, and the Nature of Government Finance'. American Journal of Political Science, 54(4): 93650.

Carter, D., and C. Signorino (2010). 'Back to the Future: Modeling Time Dependence in Binary Data’. Political Analysis, 18(3): 271-92.

Cheeseman, N. (2011). 'African Elections as Vehicles for Change'. Journal of Democracy, 21(4): 139-53.

Cheibub, J.A., J. Gandhi, and J.R. Vreeland (2010). 'Democracy and Dictatorship Revisited'. Public Choice, 143(1-2): 67-101.

Collier, P., P. Guillaumont, S. Guillaumont, and J.W. Gunning (1997). 'Redesigning Conditionality'. World Development, 25(9): 1399-1407.

Crawford, G. (1997). 'Foreign Aid and Political Conditionality: Issues of Effectiveness and Consistency’. Democratization, 4(3): 69-108.

Crawford, G. (2001). Foreign Aid and Political Reform: A Comparative Analysis of Democracy Assistance and Political Conditionality. New York: Palgrave Macmillan.

Dietrich, S. (2011). 'Does Donor Selectivity in Aid Delivery Help the Poor?' Paper presented at the Annual Meeting of the American Political Science Association, Washington, DC.

Djankov, S., J.G. Montalvo, and M. Reynal-Querol (2008). 'The Curse of Aid'. Journal of Economic Growth, 13(3): 169-94.

Dreher, A. (2006). 'The IMF and Economic Growth: The Effects of Programs, Loans, and Compliance with Conditionality’. World Development, 34(5): 769-88.

Dunning, T. (2004). 'Conditioning the Effects of Aid: Cold War Politics, Donor Credibility, and Democracy in Africa'. International Organization, 58(2): 409-23.

Electoral Institute of Southern Africa (EISA) (2012). Accessed at: http://www.eisa.org.za/. 
Epstein, D., R. Bates, J. Goldstone, I. Kristensen, and S. O’Halloran (2006). 'Democratic Transitions'. American Journal of Political Science, 50(3): 551-69.

Finkel, S.E., A. Pérez-Lián, and M.A. Seligson (2007). 'The Effects of U.S. Foreign Assistance on Democracy Building, 1990-2003’. World Politics, 59: 404-39.

Freedom House (2010). 'Freedom in the Word.' Accessed at: http://www.freedomhouse.org/report-types/freedom-world.

Geddes, B. (2003). Paradigms and Sand Castles. Ann Arbor: University of Michigan Press.

Geddes, B., J. Wright, and E. Frantz (2012). 'Authoritarian Regimes: A New Data Set'. Manuscript.

Gleditsch, N.P., P. Wallensteen, M. Eriksson, M. Sollenberg, and H. Strand (2002). 'Armed Conflict 1946-2001: A New Dataset'. Journal of Peace Research, 39(5): 615-37.

Goldsmith, A.A. (2001). 'Foreign Aid and Statehood in Africa'. International Organization, 55(1): 123-48.

Handley, A. (2008). 'The World Bank Made Me Do It? International Factors and Ghana’s Transition to Democracy’. CDDRL Working Papers 82.

Harford, T., and M. Klein (2005). 'Aid and the Resource Curse'. ViewPoints 291. The World Bank Group: Public Policy for the Private Sector.

Heckelman, J.C. (2010). 'Aid and Democratization in the Transition Economies'. Kyklos, 63(4): 558-79.

International Foundation for Electoral Systems (IFES) (2011). Accessed at: http://www.electionguide.org/.

Joseph, R. (1987). Prebendalism and Democracy in Nigeria. Cambridge: Cambridge University Press.

Kalyvitis, S., and I. Vlachaki (2010). 'Democratic Aid and Democratization of Recipients'. Contemporary Economic Policy, 28(2): 188-218.

Knack, S. (2004). 'Does Foreign Aid Promote Democracy?' International Studies Quarterly, 48(1): 251-66.

Lancaster, C. (1993). 'Governance and Development: The Views from Washington'. IDS Bulletin, 24(1): 9-15.

Lemarchand, R. (1972). 'Political Clientelism and Ethnicity in Tropical Africa: Competing Solidarities in Nation-Building'. American Political Science Review, 66(1): 68-90.

Levi, M. (1988). Of Rule and Revenue. Berkeley: University of California Press.

Lindberg, S.I. (2006). Democracy and Elections in Africa. Baltimore: The Johns Hopkins University Press.

McGillivray, M., and O. Morrissey (2001). 'Fiscal Effects of Aid'. UNU-WIDER Discussion Paper 2001/61. UNU-WIDER: Helsinki. 
Moore, M. (1998). 'Death without Taxes: Democracy, State Capacity, and Aid Dependence in the Fourth World'. In G. White and M. Robinson (eds), Towards a Democratic Developmental State. Oxford: Oxford University Press.

Moss, T., G. Pettersson, and N. van de Walle (2006). 'An Aid-Institutions Paradox? A Review Essay on Aid Dependency and State Building in Sub-Saharan Africa'. Center for Global Development, Working Paper 74.

Munck, G.L., and J. Verkuilen (2002). 'Conceptualizing and Measuring Democracy: Evaluating Alternative Indices’. Comparative Political Studies, 35(1): 5-34.

North, D., and B. Weingast (1989). 'The Constitution of Commitment: The Evolution of Institutions Governing Public Choice in Seventeenth Century England'. Journal of Economic History, 49(4): 803-31.

OECD (2010). ‘Development Statistics’. Accessed at: http://www.oecd.org.

Penn World Tables (2011). Version 7.0. Accessed at: http://pwt.econ.upenn.edu/php_site/pwt_index.php.

Pitcher, A., M.H. Moran, and M. Johnston (2009). 'Rethinking Patrimonialism and Neopatrimonialism in Africa'. African Studies Review, 52(1): 125-56.

Posner, D., and D. Young (2007). 'The Institutionalization of Political Power in Africa'. Journal of Democracy, 18(3): 126-40.

Przeworski, A., M.E. Alvarez, J.A. Cehibub, and F. Limongi (2000). Democracy and Development: Political Institutions and Well-Being in the World, 1950-1990. New York: Cambridge University Press.

Remmer, K. (2004). 'Does Foreign Aid Promote the Expansion of Government?' American Journal of Political Science, 48: 77-92.

Schedler, A. (2001). 'Measuring Democratic Consolidation'. Studies in Comparative International Development, 1(36):66-92.

Scott, J., M. Carie, and A. Steele (2011). 'Sponsoring Democracy: The United States and Democracy Aid to the Developing World, 1988-2001'. International Studies Quarterly, 55(1): 47-69.

Svolik, M. (2008). 'Authoritarian Reversals and Democratic Consolidation'. American Political Science Review, 102(2): 153-68.

Thorsten, B., G. Clarke, A. Groff, P. Keefer, and P. Walsh (2001). 'New Tools in Comparative Political Economy: The Database of Political Institutions'. World Bank Economic Review, 15(1): 165-76.

Tilly, C. (1990). Coercion, Capital, and European States. New York: Blackwell.

Van de Walle, N. (2005). Overcoming Stagnation in Aid-Dependent Countries. Washington, DC: Center for Global Development.

Von Doepp, P. (2005). 'Party Cohesion and Fractionalization in New African Democracies: Lessons from Struggles over Third-Term Amendments'. Studies in Comparative International Development, 40 (3): 65-87. 
Wilson, S., E. Daniel, and M. Butler (2007). 'A Lot More to Do: The Sensitivity of Time-Series Cross-Section Analyses to Simple Alternative Specifications’. Political Analysis, 15(2): 101-23.

World Development Indicators (WDI) (2011). Accessed at: http://databank.worldbank.org/Data/Home.aspx.

Wright, J. (2008). 'Political Competition and Democratic Stability in New Democracies’. British Journal of Political Science, 38(2): 221-45.

Wright, J. (2009). 'How Foreign Aid Can Foster Democratization in Authoritarian Regimes’. American Journal of Political Science, 53(3): 552-71. 


\section{A: Data Appendix}

Table A1: Multipartyism

\begin{tabular}{|c|c|c|c|c|c|}
\hline Country & Begin & End & Country & Begin & End \\
\hline Angola & 1993 & censored & Lesotho & 1999 & censored \\
\hline Benin & 1992 & censored & Liberia $^{\dagger}$ & 1986 & 1990 \\
\hline Botswana $^{\dagger}$ & 1967 & censored & Liberia & 1998 & 2002 \\
\hline Burkina Faso & 1993 & censored & Liberia & 2006 & censored \\
\hline Burundi & 1994 & 1994 & Madagascar & 1994 & censored \\
\hline Burundi & 2006 & censored & Malawi & 1995 & censored \\
\hline Cameroon & 1993 & censored & Mali & 1993 & censored \\
\hline Cape Verde & 1992 & censored & Mauritania & 1993 & 2005 \\
\hline $\begin{array}{l}\text { Central African } \\
\text { Republic }\end{array}$ & 1994 & 2003 & Mauritania & 2007 & 2008 \\
\hline $\begin{array}{l}\text { Central African } \\
\text { Republic }\end{array}$ & 2006 & censored & Mauritius $^{\dagger}$ & 1969 & censored \\
\hline Chad & 1998 & censored & Mozambique & 1995 & censored \\
\hline Comoros & 1993 & 1996 & Namibia & 1995 & censored \\
\hline Comoros & 2005 & censored & Niger & 1994 & 1996 \\
\hline Congo Br. & 1993 & 1997 & Niger & 1997 & 1999 \\
\hline Congo Br. & 2003 & censored & Niger & 2000 & censored \\
\hline Côte d'Ivoire & 1991 & 1999 & Nigeria & 2000 & censored \\
\hline Côte d'Ivoire & 2001 & censored & Rwanda & 2004 & censored \\
\hline DRC & 2007 & censored & São Tome & 1992 & censored \\
\hline Equatorial Guinea & 1994 & censored & Senegal & $1990^{\dagger}$ & censored \\
\hline Ethiopia & 1996 & censored & Seychelles & 1994 & censored \\
\hline Gabon & 1991 & censored & Sierra Leone & 1997 & 1997 \\
\hline Gambia $^{\dagger}$ & 1967 & 1994 & Sierra Leone & 2003 & censored \\
\hline Gambia & 1998 & censored & South Africa* & 1994 & censored \\
\hline Ghana & 1997 & censored & Tanzania & 1996 & censored \\
\hline Guinea & 1996 & censored & Togo & 1995 & censored \\
\hline Guinea-Bissau & 1995 & 2003 & Uganda & 2007 & censored \\
\hline Guinea-Bissau & 2005 & censored & Zambia & 1992 & censored \\
\hline Kenya & 1993 & censored & Zimbabwe $^{\star} \dagger$ & 1981 & censored \\
\hline
\end{tabular}

Notes: ${ }^{*}$ indicates start coded from universal suffrage; ${ }^{\dagger}$ indicates left-censored at 1990; censored $\equiv$ right-censored in 2008. Start year coded for first year (Jan1) when multipartyism is observed; this is typically the year after the first multiparty election.

Source: Cheibub et al. (2010) and authors' calculations (see footnotes 7 and 8). 
Table A2: Fairness failure

\begin{tabular}{lcclcc}
\hline Country & Begin & End & Country & Begin & End \\
\hline Benin & 1992 & Censor & Madagascar & 1994 & Censor \\
Botswana & 1990 & Censor & Malawi & 1995 & Censor \\
Burkina Faso & 2000 & 2004 & Mali & 1993 & Censor \\
Burundi & 2006 & Censor & Mauritania & 2008 & 2008 \\
Cape Verde & 1992 & Censor & Mauritius & 1990 & Censor \\
Central African Republic & 1994 & 2001 & Mozambique & 1995 & Censor \\
Comoros & 1993 & 1996 & Namibia & 1995 & Censor \\
Comoros & 2005 & Censor & Niger & 1994 & 1996 \\
Gabon & 1991 & 1993 & Niger & 2001 & Censor \\
Gambia & 1990 & 1994 & Nigeria & 2000 & 2008 \\
Gambia & 2003 & 2005 & São Tomé & 1992 & Censor \\
Ghana & 1997 & Censor & Senegal & 1990 & Censor \\
Guinea-Bissau & 1995 & 2003 & Seychelles & 1994 & Censor \\
Guinea-Bissau & 2005 & Censor & Sierra Leone & 1997 & 1997 \\
Kenya & 1993 & 1993 & Sierra Leone & 2003 & Censor \\
Kenya & 2003 & Censor & South Africa & 1995 & Censor \\
Lesotho & 1999 & Censor & Tanzania & 2000 & Censor \\
Liberia & 1998 & 2000 & Zambia & 1992 & 1996 \\
Liberia & 2006 & Censor & Zambia & 2003 & Censor \\
\hline
\end{tabular}

Notes: * indicates start coded from universal suffrage; $\uparrow$ indicates left-censored at 1990; censored $\equiv$ right-censored in 2008. Start year coded for first year (Jan1) when multipartyism is observed; this is typically the year after the first multiparty election.

Source: Authors' calculations using Freedom House (2010) and Cheibub et al. (2010). See text for details. 
Table A3: Incumbent turnover sample

\begin{tabular}{|c|c|c|c|c|c|c|}
\hline Country & Year & Country & Year Country & Year & Country & Year \\
\hline Benin & 1996 & $\begin{array}{l}\text { Equatorial } \\
\text { Guinea }\end{array}$ & 2002 Malawi & 2004 & Nigeria & 2007 \\
\hline Benin & 2001 & Gabon & 1993 Mali & 1997 & Senegal & 1993 \\
\hline Burkina Faso & 1998 & Gabon & 1998 Mali & 2002 & Senegal & 2000 \\
\hline Burkina Faso & 2005 & Gabon & 2005 Mauritania & 1997 & $\begin{array}{l}\text { Sierra } \\
\text { Leone }\end{array}$ & 2007 \\
\hline Cameroon & 1997 & Gambia & 1992 Mauritania & 2003 & Tanzania & 2000 \\
\hline Cape Verde & 1996 & Gambia & 2001 Mauritania & 2007 & Tanzania & 2005 \\
\hline Cape Verde & 2001 & Gambia & 2006 Mozambique & 1999 & Togo & 1998 \\
\hline Central African Rep & 1999 & Ghana & 2000 Mozambique & 2004 & Togo & 2005 \\
\hline Chad & 2001 & Guinea & 1998 Namibia & 1999 & Zambia & 1996 \\
\hline Chad & 2006 & Guinea & 2003 Namibia & 2004 & Zambia & 2001 \\
\hline Comoros & 1996 & $\begin{array}{l}\text { Guinea- } \\
\text { Bissau }\end{array}$ & 2000 Niger & 1996 & Zambia & 2006 \\
\hline Comoros & 2006 & Kenya & 1997 Niger & 1999 & Zimbabwe & 1996 \\
\hline Congo-Br & 2006 & Kenya & 2002 Niger & 2004 & Zimbabwe & 2002 \\
\hline Côte d'Ivoire & 1995 & Madagascar & 1996 Nigeria & 2003 & Zimbabwe & 2008 \\
\hline Equatorial Guinea & 1996 & Malawi & 1999 & & & \\
\hline
\end{tabular}

Note: Direct executive elections under incumbent multiparty regime without prior executive turnover, 1991-2008.

Source: Authors' coding using Cheibub et al. (2010) and African Elections Database (2011). 
Table A4: Term limit observations

\begin{tabular}{|c|c|c|c|c|c|c|c|c|c|}
\hline Country & $\begin{array}{l}\text { Term- } \\
\text { spell }\end{array}$ & Years & Violation & Censor & Country & $\begin{array}{l}\text { Term- } \\
\text { spell }\end{array}$ & Years & Violation & Censor \\
\hline Angola & 1 & $1992-2002$ & 1 & 0 & Madagascar & 2 & $2002-2009$ & 0 & 1 \\
\hline Burundi & 1 & $1993-2003$ & 0 & 1 & Malawi & 1 & $1994-2004$ & 0 & 0 \\
\hline Burundi & 1 & $2005-2015$ & 0 & 1 & Malawi & 2 & 2004-2014 & 0 & 1 \\
\hline Benin & 1 & $1991-2001$ & 0 & 0 & Mali & 1 & $1992-2002$ & 0 & 0 \\
\hline Benin & 2 & $2001-2011$ & 0 & 1 & Mali & 2 & $2002-2012$ & 0 & 1 \\
\hline Botswana & 1 & 1989-1999 & 0 & 0 & Mozambique & 1 & $1994-2004$ & 0 & 0 \\
\hline Botswana & 2 & $1999-2009$ & 0 & 0 & Mozambique & 2 & $2004-2014$ & 0 & 1 \\
\hline Botswana & 3 & $2009-2019$ & 0 & 1 & Namibia & 1 & $1992-1998^{*}$ & 1 & 0 \\
\hline Cameroon & 1 & $1997-2008^{*}$ & 1 & 0 & Niger & 1 & $1999-2009^{*}$ & 1 & 0 \\
\hline Cape Verde & 1 & 1996-2001 & 0 & 0 & Nigeria & 1 & $1999-2007$ & 0 & 0 \\
\hline Cape Verde & 2 & $2001-2011$ & 0 & 1 & Nigeria & 2 & $2007-2017$ & 0 & 1 \\
\hline CAR & 1 & $1999-2011$ & 0 & 1 & Rwanda & 1 & 2003-2017 & 0 & 1 \\
\hline CAR & 1 & $2005-2017$ & 0 & 1 & São Tomé & 1 & $1991-2001$ & 0 & 0 \\
\hline Chad & 1 & $1996-2005^{*}$ & 1 & 0 & São Tomé & 2 & $2001-2011$ & 0 & 1 \\
\hline Comoros & 1 & $2002-2006$ & 0 & 0 & Senegal & 1 & 1983-1993 & 1 & 0 \\
\hline Comoros & 2 & $2006-2010$ & 0 & 0 & Senegal & 1 & $1993-2000$ & 0 & 0 \\
\hline Comoros & 3 & $2010-2015$ & 0 & 1 & Senegal & 2 & $2000-2014$ & 0 & 1 \\
\hline Congo $\mathrm{Br}$. & 1 & $2002-2016$ & 0 & 1 & Seychelles & 1 & $1993-2006$ & 0 & 0 \\
\hline DRC & 1 & $2006-2016$ & 0 & 1 & Seychelles & 2 & $2006-2021$ & 0 & 1 \\
\hline Djibouti & 1 & 1993-1999 & 0 & 0 & Sierra Leone & 1 & $1996-2007$ & 0 & 0 \\
\hline Djibouti & 2 & $1999-2010^{*}$ & 1 & 0 & Sierra Leone & 2 & $2007-2017$ & 0 & 1 \\
\hline Gabon & 1 & $1993-2003$ & 1 & 0 & South Africa & 1 & $1999-2008$ & 0 & 0 \\
\hline Ghana & 1 & $1996-2000$ & 0 & 0 & South Africa & 2 & $2009-2018$ & 0 & 1 \\
\hline Ghana & 2 & $2000-2008$ & 0 & 0 & Togo & 1 & $1992-2002^{*}$ & 1 & 0 \\
\hline Ghana & 3 & 2008-2016 & 0 & 1 & Tanzania & 1 & $1995-2005$ & 0 & 0 \\
\hline Guinea & 1 & $1993-2001^{*}$ & 1 & 0 & Tanzania & 2 & $2005-2015$ & 0 & 1 \\
\hline Kenya & 1 & $1992-2002$ & 0 & 0 & Uganda & 1 & $1995-2005^{*}$ & 1 & 0 \\
\hline Kenya & 2 & $2002-2012$ & 0 & 1 & Zambia & 1 & $1991-2001$ & 0 & 0 \\
\hline Liberia & 1 & $1997-2009$ & 0 & 1 & Zambia & 2 & $2001-2008$ & 0 & 0 \\
\hline Liberia & 1 & $2005-2017$ & 0 & 1 & Zambia & 3 & $2008-2018$ & 0 & 1 \\
\hline Madagascar & 1 & $1992-2002$ & 0 & 0 & & & & & \\
\hline
\end{tabular}

Note: End year is the date of changed rule $\left(^{*}\right)$ or end of term limit when term limit failure occurs.

Source: Posner and Young (2007); Baturo (2010); VonDoepp (2005); International Foundation for Electoral Systems (IFES) (2011); Electoral Institute of Southern Africa (EISA) (2012). 
Table A5: Democracy and Governance Aid, purposes defined by AidData (2010)

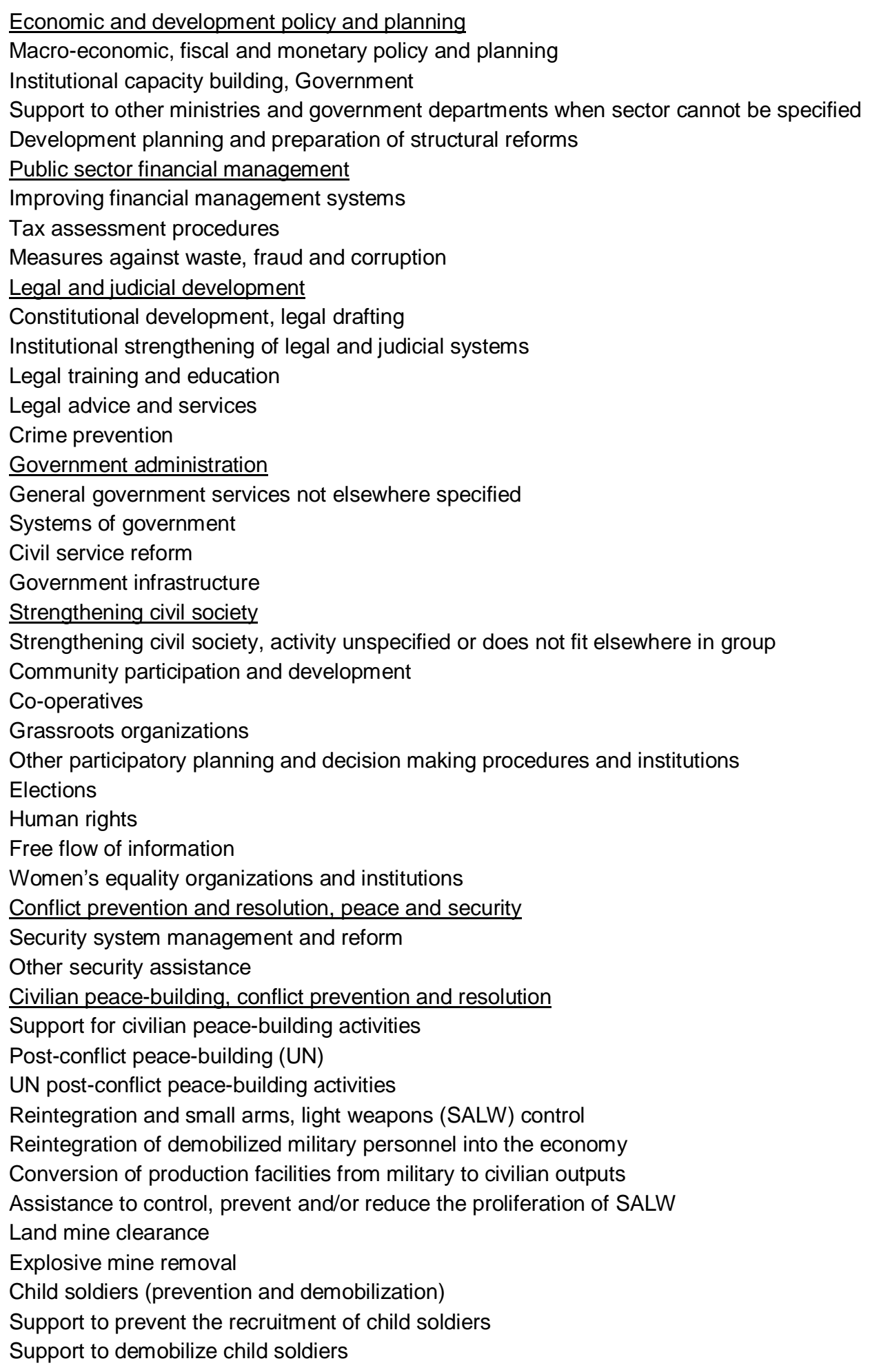

Source: AidData 2010. 
Table A6: Difference of means tests

\begin{tabular}{lccc}
\hline & Aid type & T-statistic & $\mathrm{N}$ \\
\hline Transition to multipartyism & Economic & 0.83 & 41 \\
Multiparty failure & Democracy & 0.74 & 42 \\
Incumbent turnover & Democracy & 1.02 & 30 \\
Term limit violation & Democracy & $1.68^{\star}$ & 28 \\
\hline
\end{tabular}

Notes: Difference of means test for country-mean level of aid, grouped by whether the dependent variable is every positive (i.e. whether failure occurs at some point). Aid means calculated from 1991-2008 when under a multiparty regime, except for transition to multipartyism, where the mean is for the years 1986-2008 when not under a multiparty regime. Observations are the number of countries in the respective samples.

Source: Authors' calculations.

Figure A1: Historical party institutions, by country

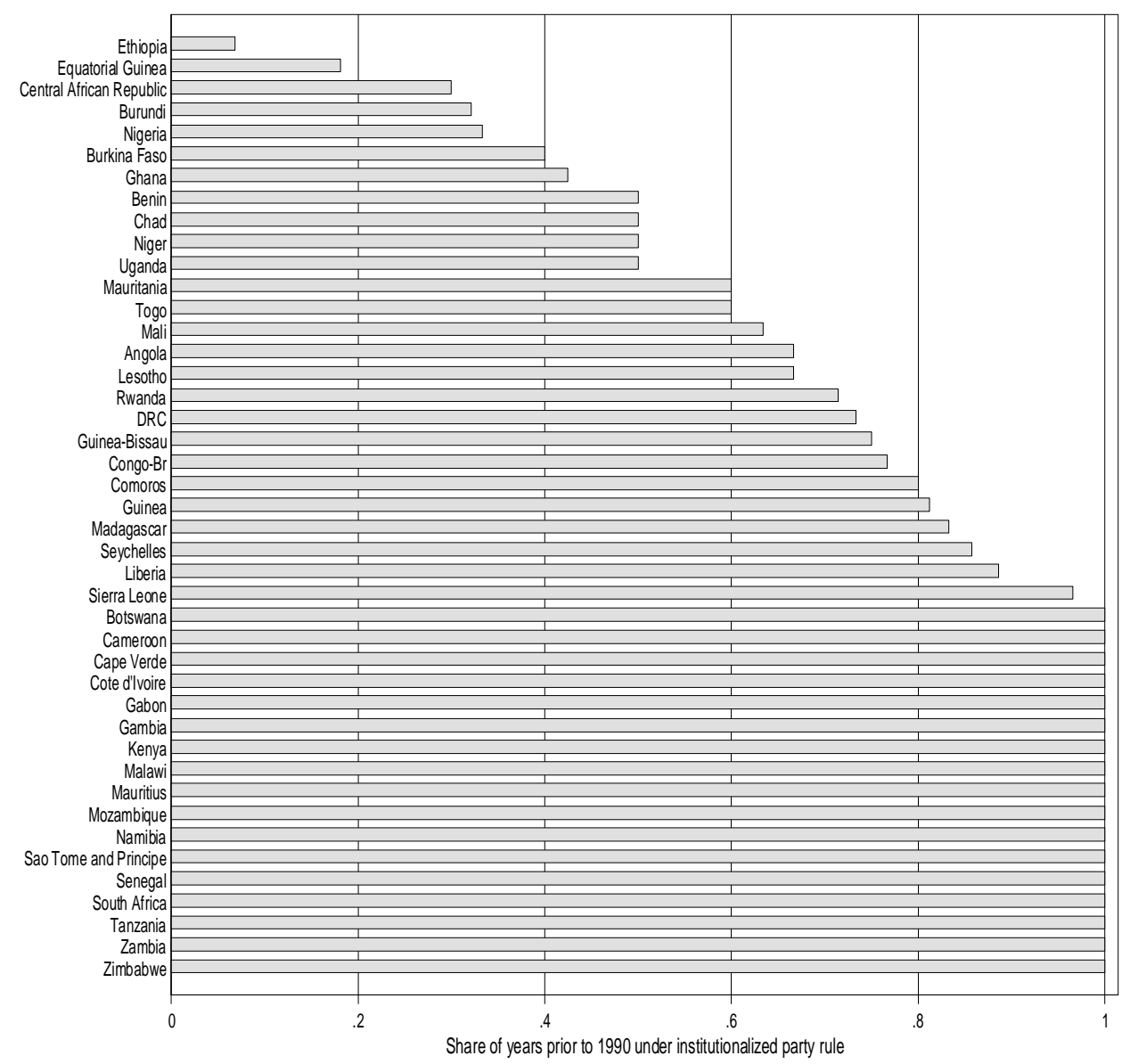

Notes: Share of years since independence up to 1989 with at least one party represented in an elected legislature. Time invariant for post-1989 period.

Source: Analysis based on data from Cheibub et al. (2010). 
Figure A2: Historical personalist rule, by country

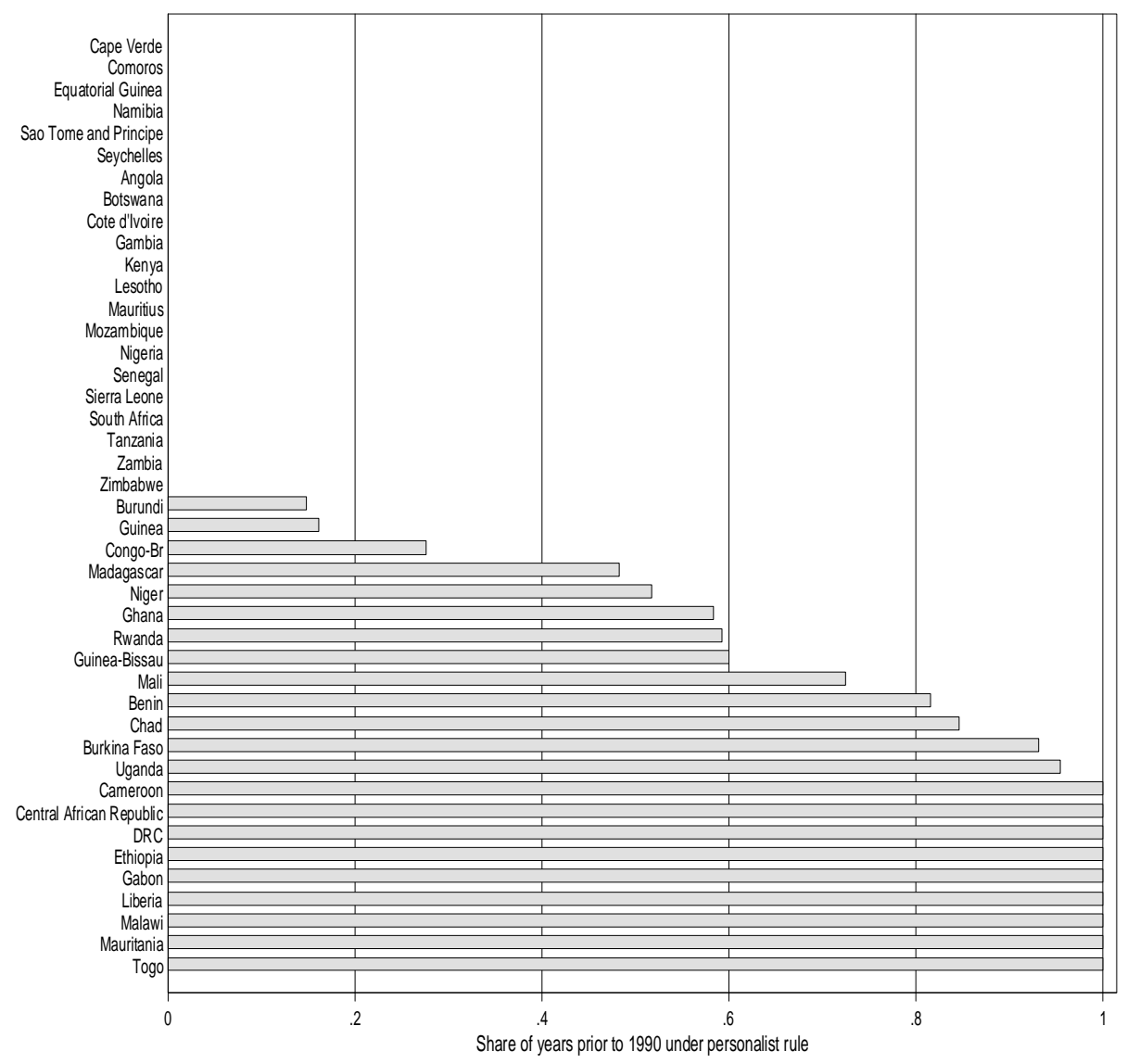

Notes: Share of years since independence up to 1989 in which a personalist dictator ruled. Time invariant for post-1989 period.

Source: Analysis based on data from Geddes et al. (2012). 